\title{
Substrate type and palaeodepth do not affect the Middle Jurassic taxonomic diversity of crinoids
}

\author{
Mariusz A Salamon $^{\text {Corresp., } 1}$, Anna Feldman-Olszewska ${ }^{2}$, Sreepat Jain ${ }^{3}$, Bruno Ferré ${ }^{4}$, Karolina Paszcza ${ }^{5}$, Bartosz J \\ Płachno ${ }^{6}$ \\ ${ }^{1}$ Faculty of Natural Science, University of Silesia in Katowice, Sosnowiec, Poland \\ 2 National Research Institute, Polish Geological Institute, Warszawa, Poland \\ 3 Department of Applied Geology, School of Applied Natural Sciences, Adama Science and Technology University, Adama, Ethiopia \\ 4 Saint Étienne du Rouvray, Saint Etienne, France \\ 5 Faculty of Natural Sciences, University of Silesie in Katowice, Sosnowiec, Poland \\ ${ }^{6}$ Faculty of Biology, Institute of Botany, Jagiellonian University in Kraków, Kraków, Poland \\ Corresponding Author: Mariusz A Salamon \\ Email address: paleo.crinoids@poczta.fm
}

Crinoids are largely considered as good indicators for determining environmental conditions. They are robust proxies for inferring changes in salinity and sedimentation rate and for inferring substrate type. Some crinoid groups (e.g., certain comatulids, cyrtocrinids, millericrinids) have a depth preference, thus, making them useful for paleodepth estimation. The hypotheses that crinoid distribution is substrate-dependent (rock type) or palaeodepth-dependent is tested here based on (a) archival BathonianCallovian (Middle Jurassic) crinoid occurrences from Poland and (b) newer finds from five boreholes from eastern Poland. Qualitative data suggests that isocrinids and cyclocrinids occur in both carbonate and siliciclastic rocks. The cyrtocrinids and roveacrinids occur within carbonate rocks, whereas the comatulids are exclusive to siliciclastics. In terms of palaeodepth, most crinoid groups dominate in shallow environments with the sole exception of cyrtocrinids, that are ubiquitous and occur in both shallow (near shore and shallow marine) and slightly deeper (deeper sublittoral to open shelf) settings. The occurrences of the cosmopolitan taxa, Chariocrinus andreae and Balanocrinus subteres (isocrinids), is independent of both substrate type and paleodepth. Quantitative analyses (Analysis Of Variance; ANOVA) based on substrate type, i.e., substrate-dependency (claystones, sandstones and limestones), and palaeodepth i.e., palaeodepth-dependency (near shore, shallow-marine, mid-ramp and off shore), corroborate qualitative results. Statistical analysis suggest that the distribution of crinoids shows a strong substratedependency but not for palaeodepth, although very weak significance (low p value) is noted for near shore and shallow marine settings and crinoid distribution. 
1 Does substrate type and palaeodepth affect the Middle Jurassic taxonomic diversity of

2 crinoids?

3

4 Mariusz A. SALAMON $^{1}$, Anna FELDMAN-OLSZEWSKA ${ }^{2}$, Sreepat JAIN $^{3}$, Bruno FERRÉ ${ }^{4}$,

5 Karolina PASZCZA ${ }^{1}$, Bartosz PŁACHNO ${ }^{5}$

6

1 University of Silesia, Faculty of Earth Sciences, Department of Palaeontology and Stratigraphy,

8 Będzińska 60, 41-200 Sosnowiec, Poland; e-mail: paleo.crinoids@poczta.fm

92 Polish Geological Institute - National Research Institute, Rakowiecka 4, 00-975 Warszawa,

10 Poland; e-mail: anna.feldman-olszewska@pgi.gov.pl

11 Adama Science and Technology University, Department of Applied Geology, School of

Applied Natural Sciences, P.O. Box 1888, Adama, Ethiopia

4 rue Guy de Maupassant, F-76800 Saint Étienne du Rouvray, France; e-mail:

bruno_ferre@yahoo.com

5 Jagiellonian University in Kraków, Faculty of Biology, Institute of Botany, Gronostajowa

Street 9, 30-387 Cracow, Poland; e-mail: bartosz.plachno@uj.edu.pl

Abstract

Crinoids are largely considered as good indicators for determining environmental conditions. They are robust proxies for inferring changes in salinity and sedimentation rate and for inferring substrate type. Some crinoid groups (e.g., certain comatulids, cyrtocrinids, millericrinids) have a depth preference, thus, making them useful for paleodepth estimation. The hypotheses that crinoid distribution is substrate-dependent (rock type) or palaeodepth-dependent is tested here based on (a) archival Bathonianboreholes from eastern Poland. Qualitative data suggests that isocrinids and cyclocrinids occur in both carbonate and siliciclastic rocks. The cyrtocrinids and roveacrinids occur within carbonate rocks, whereas the comatulids are exclusive to siliciclastics. In terms of 
palaeodepth, most crinoid groups dominate in shallow environments with the sole exception of cyrtocrinids, that are ubiquitous and occur in both shallow (near shore and shallow marine) and slightly deeper (deeper sublittoral to open shelf) settings. The occurrences of the cosmopolitan taxa, Chariocrinus andreae and Balanocrinus subteres (isocrinids), is independent of both substrate type and paleodepth. Quantitative analyses (Analysis Of Variance; ANOVA) based on substrate type, i.e., substrate-dependency (claystones, sandstones and limestones), and palaeodepth i.e., palaeodepth-dependency (near shore, shallow-marine, mid-ramp and off shore), corroborate qualitative results. Statistical analysis suggest that the distribution of crinoids shows a strong substratedependency but not for palaeodepth, although very weak significance (low p value) is noted for near shore and shallow marine settings and crinoid distribution.

Key words: echinoderms, crinoids, Jurassic, Bathonian, Callovian, Poland, boreholes.

\section{Introduction}

The Middle Jurassic (especially Bajocian and Callovian) strata of the epicratonic Poland (Central European province $=$ Submediterranean province) are well-known for their excellently preserved and strongly diversified fossil fauna and flora (e.g., Kopik, 1974, 1976, 1979a, b, 1998, 2006; Zatoń et al., 2006a, b). These occur within clays and carbonate concretions and are represented by ammonites, gastropods, scaphopods, bivalves, belemnites, brachiopods, bryozoans, echinoids, asteroids, ophiuroids, wood fragments, and many others (for details see Matyja \& Wierzbowski, 2000, 2003; Gedl et al., 2003; Kaim, 2004; Zatoń \& Marynowski, 2004, 2006; Zatoń et al., 2006a, b; Zatoń, 2010a, b). Crinoids, the group under study, are also diverse and abundant (more so in the boreholes of eastern Poland), and often form encrinites (a grain-supported bioclastic sedimentary rock) in which all or most of the grains are crinoid ossicles (e.g., Salamon \& Feldman-Olszewska, 2018). Despite such rich diversity and abundance, the crinoid data from the Middle Jurassic of Poland has largely been relegated to either brief mentions of species occurrences or of citing crinoid-yielding localities (see Salamon \& Feldman-Olszewska, 2018 and literature cited therein). 
The present Middle Jurassic study, based on new data from five eastern Poland boreholes (see Fig. 1 and Table 1) and previously published crinoid records has twin objectives: (a) to standardize crinoid taxonomic disparity with added remarks on systematic issues and previous collections, and, (b) to test two hypotheses using this standardized dataset. These include: (1) Do crinoids occur equally and frequently in both terrigenous and carbonate facies (test for substratedependency)? and, (2) Do crinoids occur equally and frequently in both deep and shallow water environments (test for palaeodepth-dependency)? Besides, qualitative analysis, the Analysis Of Variance (ANOVA) is used to quantitatively test these two hypotheses.

During the Bathonian-Callovian duration, the Polish Basin was part of the epicratonic Central European Basin that separated the Fennoscandian plains on the north from the Western Tethys to the south. Only the extreme southern part of Poland (Tatra Mountains and Pieniny Klippen Belt) was part of the Tethyan realm (see Fig. 1). These two realms display distinct provincial characteristics (as evident from the distribution of ammonites; see Hallam, 1975; Brand, 1986), but this provincialism is not noted for crinoids. Hence, this study, also analyses crinoid taxonomic diversity trends between these two palaeobiogeographic provinces, i.e., Tethyan and Central European.

\section{Figure 1 around here}

\section{Previous records}

The Middle Jurassic (Callovian) crinoids of the epicratonic basins of Poland have been recorded from the Polish Jura Chain ('A' on Fig. 1) and the Mesozoic margin of the Holy Cross Mountains ('B' on Fig. 1). Early records only mentioned crinoid localities (e.g., Wójcik, 1910; Makowski, 1952; Różycki, 1953). Later, Dayczak-Calikowska (1980) listed several taxa but did not mention the exact locations from where the crinoid specimens were collected or where they were kept (sample repository). Furthermore, neither description, nor illustration, or even basic taxonomic group assignment was provided; most, however, belong to balanocrinids. Radwańska \& Radwański (2003) from northern Poland recorded Callovian columnals of Cyclocrinus macrocephalus and Oxfordian cyclocrinid of Cyclocrinus couiavianus. Salamon \& Zatoń (2006) from the Callovian marly limestones of the Zalas Quarry in southern Poland ('A' in Fig. 1; see 
90

91

92

93

94

95

96

97

98

99

100

101

102

103

104

105

106

107

108

109

110

111

112

113

114

115

116

117

118

119

120

also Table 2) erected a new species of balanocrinid (Balanocrinus hessi); this was later

synonymized with $B$. pentagonalis by Krajewski et al. (2019). Salamon \& Gorzelak (2007), from the same locality (Zalas Quarry in southern Poland; 'A' in Fig. 1) described few isolated remains of indeterminable cyrtocrinids associated with the cyrtocrinid cup of Dolichocrinus cf. aberrans (see Table 2). Salamon \& Zatoń (2007) from a collection of $\sim 1500$ remains of columnals, pluricolumnals, brachials and cups, illustrated 11 crinoid taxa, including some isocrinids, comatulids, millecrinids and cyclocrinids (see Table 2). These specimens came from three Bajocian, four Bathonian and two Callovian localities of the southern part of the Polish Jura Chain and the Mesozoic margin of the Holy Cross Mountains (see Salamon \& Zatoń, 2007). Current re-examination of this material led to the assignment of the columnals described as Millericrinina to the cyrtocrinids, Cyrtocrinida indet. (see Salamon \& Feldman-Olszewska, 2018) (Table 2). Salamon (2008a, b) from two Callovian localities (Polish Jura Chain, 'A' in Fig. 1 and the "glacial drift" of Łuków in eastern Poland: ' $C$ ' in Fig. 1) recorded several crinoid taxa. The "glacial drift" assemblage of Łuków ('C' in Fig. 1) is dominated by isocrinids with associated comatulids. The carbonate rocks of the Polish Jura Chain yielded a rich assemblage of cyrtocrinids with dozens of complete individuals and a few isolated isocrinid remains. Salamon \& Feldman-Olszewska (2018) from the Callovian crinoidal limestones of the Żebrak IG 1 borehole (eastern Poland; 'D' in Fig. 1) described a-collection of five isocrinid taxa with some unidentifiable cyrtocrinids (see also Table 2). This collection contained a relatively small number of complete or nearly complete individuals, as a side-effect of the maceration process. Before the maceration process, the samples formed a typical encrinite and consisted largely of crinoids, as is also the case in the present study, yielding only fragmentary crinoids (see Table 2). Additionally, the Middle Jurassic (Bathonian-Callovian carbonates) exposures in southern Poland (Tethyan province, ' $\mathrm{E}$ ' and ' $\mathrm{F}$ ' in Fig. 1) have also yielded isocrinids, cyrtocrinids, roveacrinids, and cyclocrinids (see Głuchowski, 1987; see Table 2).

\section{Material and methods}

The archival cores (72 core samples) drilled in eastern Poland (G1-G5 on Figs. 1 and 2) were investigated for crinoids. These cores are stored in the Polish Geological Institute National Research Institute, Warsaw (Poland). The samples selected for the maceration process were 
121 selected from the following boreholes at respective depths: 1) Kock IG 2 (core depth: 859.0 m;

122 age: Callovian?); 2) Maciejowice IG 1 (core depth: 1,431.5 m; age: late Bathonian?); 3)

123 Magnuszew IG 1 (core depths: 1,505.7 m, 1,507.3 m, 1,508.65 m, and 1,522.4 m; age: middle

124 and late Callovian respectively); 4) Siedliska IG 1 (core depths: $824.65 \mathrm{~m}, 828.25 \mathrm{~m}, 828.77 \mathrm{~m}$,

$125830.8 \mathrm{~m}$, and $837.65 \mathrm{~m}$; age: late Bathonian?-early Callovian); 5) Tłuszcz IG 1 (core depth:

126 1,047.7 m and 1,049.95 m; age: late Callovian?-early Oxfordian); 6) Żyrzyn IG 1 (core depths:

127 1,134.95 m, 1,137.7 m, 1,147.9 m, and 1,155.4 m; age: late Bathonian-Callovian) (for a

128 summary see Table 2).

129 The present paper also includes a large collection of Callovian crinoids from Poland

130 collected by Mariusz Salamon and Bartosz Płachno (2006-present) and others, mentioned in the

131 Acknowledgements section.

132 The first step for the current analysis consisted of examining the drill cores under a

133 binocular microscope for crinoids. Thereafter, the carbonate samples were soaked with Glauber's

134 salt. Based on sample cohesion, these were then successively boiled and freezed. The residue

135 was then washed under running tap water and sieved (mesh sizes: Ø1.0, 0.315 and $0.1 \mathrm{~mm}$,

136 respectively). The final step consisted of drying the screened residue at $170-180^{\circ} \mathrm{C}$ (following the

137 methodology outlined by Krajewski et al., 2019).

138 Both the sandstone sample Maciejowice IG 1 (core depth: 1,431.5 m; age: late

139 Bathonian?) and the carbonate sample Magnuszew IG 1 (core depth: 1,505.7 m; age: late

140 Callovian) were naturally macerated and left outside for 30 days (from January 22 nd to February

$\left.14121^{\text {st }}, 2021\right)$. As a result of this natural maceration, the samples were partially disintegrated. In

142 addition to this, several thin sections (TS) and polished slabs (PS) were also made. All crinoids

143 were hand-picked from the maceration residue and photographed using a Canon Eos 350D

144 digital camera, LeicaWildM10 coupled with a NikCamPro1 microscope and a Scanning Electron

145 Microscope Philips XL-20. All specimens are housed in the Institute of Earth Sciences of the

146 University of Silesia in Katowice, Poland, and catalogued under registration number GIUS 8-

147 3734. Other Middle Jurassic specimens used in the current study are also housed at the Institute

148 of Earth Sciences of the University of Silesia in Katowice, Poland, and catalogued under: GIUS

149 8-2510, 8-2569, 8-2571, 8-3460Cr, 8-3466, 8-3678/1-6, 8-3734. 
151

152

153

154

155

156

157

158

159

160

161

162

163

164

165

166

167

168

169

170

171

172

173

174

175

176

177

178

179

180

181

\section{Statistical methods}

The taxonomically standardized dataset was subjected to Analysis Of Variance (ANOVA). To check for substrate-dependency (Hypothesis 1), the dataset was categorized under claystones, sandstones and limestones (the former two represent siliciclastics, whereas the latter, carbonates). For palaeodepth-dependency (Hypothesis 2), the dataset was categorized under near shore, shallow-marine, mid-ramp and off shore categories. For pairwise comparisons, the Tukey's HSD (honestly significant difference) test was applied.

\section{Table 1 around here}

\section{Taxonomic standardisation}

The cyrtocrinids are identified at the specific level based on their cups. In some cases, when the cups are fragmentary or some typical features are not visible, the samples were assigned to the generic level, only. Most of the disarticulated remains of cyrtocrinids (holdfasts, columnals, radials, basals, brachials, etc.) are assigned under Cyrtocrinida indet.

As for comatulid centrodorsals, where cups with basals and radials were not available for additional information, they were also classified at the generic level. The brachial with muscular articulation on the proximal side and syzygial one on the distal side are classified as Paracomatulidae sp. et gen. indet.

The isolated remains of isocrinids, consisting of columnals, pluricolumnals, cirrals, cup plates, and brachials, are classified at the specific level. If they were found in different levels, they are described as Isocrinida indet.

A complete individual of cyclocrinid has not been found so far. Despite this, the uniqueness of their remains (e.g., large cylindrical columnals with peculiar tuberculate facets) allows us to identify them at the specific level (see detailed discussion in Radwańska \& Radwański, 2003). Głuchowski (1987) assigned some remains from the Pieniny Klippen Belt to Cyclocrinus sp. due to the incompleteness of columnals. Głuchowski (1987) classified all roveacrinids (saccocomids) as Saccocoma sp.; these were recorded either as isolated cup remains or observed in thin sections (TS). 
182

183

184

185

186

187

188

189

190

191

192

193

194

195

196

197

198

199

200

201

202

203

204

205

206

207

208

209

210

211
Thus, the dataset used in the present study is taxonomically standardised. The crinoids classified in the present study are given in Tables 1-4. A summary of all data with their respective inferred palaeodepth and species diversity (number of taxa) is given in Table 3 (see also Fig. 3).

\section{Tables 2, 3 around here}

\section{Results}

The present study identified several crinoid remains of cups, columnals, cirrals and brachials from the 5 boreholes drilled in eastern Poland (Fig. 1). Only two pluricolumnals were recorded. The first one consists of three or four columnals observable on the surface of a rock fragment from the Magnuszew IG 1 core (depth: 1,505.7 m). The second one consists of two columnals and comes from the sample of Siedliska IG 1 (depth: $828.77 \mathrm{~m}$ ). The other echinoderms observed on slab surfaces include numerous partly preserved cidaroid spines, cidaroid interambulacral plates and asteroid marginal plates. The echinoderm remains were also observed in thin sections and on the surface of polished slabs. In addition to these echinoderm remains, bivalves, gastropods and ostracods were observed both on the slab surfaces and in the macerated residues. In the late Bathonian sample Maciejowice IG 1, the remains of carbonized plant remains were also observed (for a summary of the above data see Table 4). In general, the Bathonian and Callovian crinoid assemblages are almost identical (see also Table 1). The other investigated Middle Jurassic crinoids were represented by numerous cups, cup remains, brachials, columnals, pluricolumnals, cirri, cirrals, and holdfasts (for details see Głuchowski, 1987; Salamon \& Gorzelak, 2007; Salamon \& Zatoń, 2007; Salamon, 2008a-c; Salamon \& Feldman-Olszewska, 2018).

\section{Table 4 around here}

\section{State of preservation}


212 The preservation of crinoids was examined only on the non-macerated surfaces of fresh core

213 fragments. These were screened for signs of abrasion, bioerosion traces, chemical alteration of 214 ossicle structure, evidence of epibionts and predation traces. Most of the crinoids display a high

215 degree of disarticulation (almost 100\%). However, they are all well preserved and do not show

216 any traces of lateral surface abrasion. Excellent preservation and lack of abrasion are also noticed

217 for columnal articular surfaces; the crenulae, petal floors, perilumens and lumens are complete.

218 The two pluricolumnals also show no signs of abrasion. Additionally, the studied crinoid remains

219 are very rarely bioeroded (bioerosion was only noticed in case of three columnals in the form of

220 small and rounded holes). These may be ascribed to acrothoracican cirripedes, algae, fungi,

221 polychaetes, sipunculans, or to sponge activities (for more details see Salamon \& Zatoń, 2006;

222 Zatoń et al., 2007; Salamon \& Gorzelak, 2010).

223 Donovan (1991) suggested that under normal oxygenated conditions, complete crinoid

224 disarticulation takes place within two weeks. However, Brett et al. (1997) argued that under

225 certain circumstances, complete disarticulation may occur even after a year. In living comatulids,

226 disarticulation starts just after death and by the end of the first week, only isolated calyx and a

227 few arm fragments remain articulated (Ausich, 2001). Under high water temperatures and with

228 increased physical disturbance, the disarticulation process significantly speeds up (see Ausich,

229 2001; Hess, 2006). Baumiller \& Ausich (1992) noted that after 19 days, the isocrinid stem

230 disarticulates into noditaxes and after 22 days, the column segments get disarticulated into

231 isolated columnals. Gorzelak \& Salamon (2013) noted that under high-energy conditions

232 (constant transportation), and at room temperature, disarticulation of the crinoid skeleton is

233 nearly complete after 17 days, where only a few articulated arms and cirral ossicles remain

234 intact.

235 In the present study, the crinoid remains are preserved as cups, isolated columnals,

236 brachials, and cups. Therefore, these remains can confidently be classified as taphonomic types 2

237 and 3 sensu Brett et al. (1997). Type 2 includes isocrinids with some remains of cyrtocrinid that

238 undergo rapid postmortem disarticulation, on account of weak sutures. Type 3 comprises of

239 cyrtocrinid cups in which major portions of the skeleton are resistant to disarticulation.

240 Thus, for the present study, all the data suggest that the recorded crinoids are

241 autochthonous with negligible or no post-mortem transportation. Possibly, after death, they

242 remained for some time on the sea bottom, but were not subjected to significant transportation or 
243 reworking before burial, or they were shortly covered by sediment, as suggested by the lack of

244 abrasion surfaces. Bearing this in mind we assume little time-averaging that might alter the

245 palaeoecological and palaeodepth information. Additionally, no trace of chemical alteration,

246 predation traces and epibionts were noticed, suggesting that the inferred palaeoecological and

247 palaeodepth signals are primary.

248

249 Statistical analyses

250

251 Substrate dependency (Hypothesis 1)

252 The ANOVA test (Table 5a) yielded a statistically significant differences among the fauna of the

253 different substrate types (claystones, sandstones and limestones) at $p<.001$. For pairwise

254 comparisons, the Tukey's HSD (honestly significant difference) test was applied (Table 5b). This

255 yielded a significant difference between both claystones-sandstones and limestones but no

256 significance difference between claystones and sandstones (both being siliciclastics; Table 5b).

257

258 Palaeodepth-dependency (Hypothesis 2)

259 The comparison between paleodepth parameters (near shore, shallow-marine, mid-ramp and off

260 shore) did not yield any statistically significant results (Table 5c). The pairwise comparisons,

261 Tukey's HSD test (Table 5d) retained a statistically significant difference only between the first

262 two variables (Near shore and Shallow marine); although, the $\mathrm{p}$ value is very low ( $\mathrm{p}>0.01$ ).

263

264

Table 5 around here

265

266

\section{Discussion}

267

268

Depositional environment of the eastern part of the epicontinental Polish Basin

269

270

Upper Bathonian and Callovian of the eastern part of Polish Basin are represented by

271

organodetritic, mostly crinoidal limestones with abundant limonite. There are grainstones and

272 packstones which are dominated by echinoderm plates, less frequently appear echinoid spines, bryozoans, bivalves and brachiopods, occasionally gastropods, foraminifera, ammonites and 
274 belemnites are present. Quartz grains are frequently an admixture. In places also ferruginous

275 ooids are present. Sedimentary environment is interpreted as a mid-ramp located between normal 276 and storm wave base (Feldman-Olszewska, 2018).

277

278

Depositional environment of the Łuków glacial draft

279

280

281

282

283

284

285

286

287

288

289

290

291

292

293

294

295

296

297

The Łuków glacial drift exposed in eastern Poland (' $\mathrm{C}$ ' in Fig. 1), is a 30 m-thick Callovian unit containing black clays with carbonate concretions (see also Mizerski \& Szamałek, 1985), deposited in an offshore setting (e.g., Olempska \& Błaszczyk, 2001; Kaim, 2004). However, recently, based on the presence of a high diversity asteroid assemblage, a varied environment (ranging from coastal to deep-shelf) was proposed (Villier, 2008). This unusually high crinoid diversity is likely a reflection of ossicles being transported by currents from shallow- to deepwater offshore environments (Villier, 2008). However, according to Salamon (2008a), based on the ecology of crinoids, the Łuków clays was deposited in a relatively shallow environment and contrary to asteroids, they were not transported. Based on the presence of macro- and microremains of land flora, a nearshore environment was also inferred (see also Brand, 1986;

Marynowski et al., 2008). Similarly Gedl (2008) using dinoflagellate cysts concluded that these originated presumably from shallow marine environments. Sedimentological investigations of the Aalenian-Bathonian (Middle Jurassic) claystones and shales from central Poland indicate that their sedimentation took place in offshore (below storm wave base) and transition (between normal and storm wave base) zones of the epeiric sea (see Feldman-Olszewska, 2007, 2008, 2012a, b; Pieńkowski et al., 2008). Water depth corresponds to the Cruziana ichnofacies but shallower than the Zoophycus ichnofacies (see Knaust \& Bromley, 2012). The same depositional environment is expected for the Callovian clays from Łuków.

\section{Problems with isolated isocrinid classification}

The isocrinids are a dominant crinoid group in the Middle Jurassic sediments of Poland. However, their correct classification into families and genera is very complicated. The ideal situation is when complete crinoid findings are available (e.g., Simms, 1989; Hess, 1999c, d; 
305

306

307

308

309

310

311

312

313

314

315

316

317

318

319

320

321

322

323

324

325

326

327

328

329

330

331

332

333

334

335

of preservation). There are of course also isocrinids that have a unique structure of columnals and it is easier to identify them from others. A classic example is that of Balanocrinus subteres or B. pentagonalis (see Klikushin, 1992; Hess, 2014a, b; Krajewski et al., 2016, 2019, 2020). Hess $(2014 \mathrm{a}, \mathrm{b})$ stated that the columnals of $B$. subteres could be associated with its isolated calyx elements. Likewise, with remains of Pentacrinites dargniesi or Isocrinus nicoleti display a unique shape and ornamentation of their articular facets, as also P. dargniesi with its characteristic, ellipsoidal cirrals.

However, there is an issue with non-balanocrinid isocrinids, that have columnals of a similar morphology, and were erected on the basis of isolated skeletal remains. There are many such forms in the Middle and Upper Jurassic strata of Poland. According to de Loriol (1887), the most similar taxon to Isocrinus amblyscalaris is I. munieri. But there are some noticeable differences between them, also i.e., the height of columnals and the ornamentation of the latera. Hess (2014a) added that Pentacrinus pellati with low columnals alternating with higher ones, and ridges occurring on its latera, is also a very similar form. He concluded that both species are of middle Oxfordian age and therefore may be conspecific. In turn, Bather (1898) suggested that I. amblyscalaris collected from the Oxfordian and Kimmeridgian of Poland is a synonym of I. pendulus. Hess (1975) added that both these species originated from the same middle Oxfordian strata (Bärschwil Fm, NW Switzerland). On the other hand, Klikushin (1992) stated that there is a series of morphological differences between these two species that supersedes Bather's (1898) opinion. The latter author, elsewhere in his monograph, however, proposed to consider I. pendulus, Oxfordian I. amblyscalaris, and Callovian-Oxfordian I. oxyscalaris as junior synonyms of the Oxfordian I. desori. Krajewski et al. (2019) differed from this view and emphasized that there are some differences in the facet morphology of the mentioned taxa. Apart from the differences in the articular facets (i.e., the presence of deep furrows between petal floors), the shape of columnals may also be different (compare Hess, 1975, p. 55, text-fig. 8, pl. 19, fig. 4; Klikushin, 1992, pl. 11, fig. 1-7 vs. pl. 13, fig. 8-10; Radwańska, 2005, fig. 8/4; Salamon, 2009a, fig. 2H).

Taking into account all of the above, it is difficult to say unequivocally whether there are one or more biological species within the Middle/Upper Jurassic strata of Poland. Therefore, such forms, whose taxonomic affiliation raises serious doubts (Balanocrinus berchteni, Isocrinus bajocensis, I. bathonicus, and I. pendulus), must be evaluated with great caution in any analysis. 
337 Taxonomic status of cyclocrinids

338

The Cyclocrinids (Cyclocrinidae) were classified by Biese (1935-1937) as millericrinids

(Millericrinida, Apiocrinitidae). Sieverts-Doreck (1953, in Ubaghs) and later Hess (1975) placed

the cyclocrinids within cyrtocrinids (Cyrtocrinida). According to Radwańska \& Radwański (2003) cyclocrinid columnals are elements of radical cirrals and therefore belong to bourgueticrinids (Bourgueticrinida). Following Hess (2008), the ordinal position of Cyclocrinus and of the family Cyclocrinidae is left in the open nomenclature though the form has some resemblance to the Early Jurassic millericrinid genus Amaltheocrinus. Hess \& Messing (2011) placed Cyclocrinus within uncertain order pending proper classification of its cup plates that still remain unknown.

One of the previously investigated Callovian sections (the abandoned Wysoka Quarry placed within the Polish Jura Chain; 'A' in Fig. 1), exposes sandy limestones where numerous cyclocrinid columnals were collected from a narrow level. Remains of other crinoids were not found there. Along with these columnals, several "millericrinid"-like brachial (see Fig. 3) plates were found, which probably belong to the same crinoid as the columnals. Brachials display a proximal synostosis and a muscular distal side, sometimes with a pinnule socket. Both facets are parallel. This seems to confirm Hess's (2008) idea of linking cyclocrinids to millericrinids. On the other hand, the "bourgueticrinid"-like, strongly abraded cup was found by us in the Czerwieniec locality. This cup is very similar in shape and size to bourgueticrinid cup that may suggest that cyclocrinids really belong to bourgueticrinids as suggested by Radwańska \& Radwański (2003).

Figure 3 around here

Cyclocrinids from Poland

Wójcik (1910) first listed the occurrence of Cyclocrinus macrocephalus in Poland and the occurrence of columnals in the sands of Filipowice, Polish Jura Chain ('A' in Fig. 1). 
367 Bathonian and/or Callovian crinoidal limestones of the Tatra Mountains and the Pieniny Klippen

368 Belt ('E' and 'F' in Fig. 1). Radwańska \& Radwański (2003) questioned this assignment, 369 claiming that the sketches and photographs are not of sufficient quality, specimens are poorly

370 preserved, and that the 'cyclocrind' were small-sized. Re-examinations of Głuchowski

371 specimens (1987, fig. 13/1, 13/4 and pl. 1, fig. 1-6), stored at the Institute of Earth Sciences of

372 the University of Silesia in Katowice, Poland, prove that they are significantly smaller than the

373 columnals collected from other areas. Additionally, they are cylindrical, low and with a slightly

374 convex latera, suggesting that they may well belong to cyclocrinids. Therefore, the original

375 designations of Głuchowski (1987) are currently upheld. Moreover, Radwańska \& Radwański

376 (2003) recognized four cyclocrinid species within the Middle and Upper Jurassic strata of

377 Poland, namely: Cyclocrinus rugosus from the Bajocian, C. macrocephalus from the Callovian,

378 C. areolatus from the Oxfordian, and C. couiavianus from the upper Oxfordian. They stated that

379 all mentioned taxa (with the exception of C. couiavianus) lie within the variability of C. rugosus

380 (Radwańska \& Radwański, 2003). Though describing columnals with articular surfaces covered

381 by numerous and irregular tubercles, Salamon \& Zatoń (2007) included these remains under

382 C. macrocephalus. Re-observation of columnals coming from the same Callovian levels of the

383 Polish Jura Chain, both ornamented by and devoid of tubercles, confirm the suggestion of

384 Radwańska \& Radwański (2003) that all these cyclocrinids actually belong to a single species,

385 Cyclocrinus rugosus.

386

387 Distribution of crinoids within particular facies. Does it really work?

388

389

390

Hans Hess in several of his papers pointed out that the occurrence of certain species of crinoids may be closely related to or strictly defined by substrate (sediment type) and palaeodepth. He claimed that Chariocrinus andreae inhabited muddy bottoms and its dense colonies occurred in somewhat deeper waters, below fair-weather wave base, i.e., at depths around 10-15 m (Hess, 1972, 1999a). In this study, Chariocrinus andreae occurs in large amount in both carbonate and siliciclastic rocks. Balanocrinus subteres is one of the most cosmopolitan crinoid ever recorded in the Mesozoic and is known from both shallow and deeper environments (compare Table 3 and Fig. 2). Hess (1999a) claimed that another very common Middle Jurassic crinoid taxon, Isocrinus 
398 shelf and in slightly deeper environments (intercalating marls and bioclastic limestones). Tang et 399 al. (2000) recorded I. nicoleti from the shallow-water tidal facies of the Middle Jurassic Carmel 400 Formation in Mount Carmel Junction and also from the open shallow subtidal (carbonate) facies 401 of the Gypsum Spring and Twin Creek Formations of Wyoming (USA). Hunter \& Underwood 402 (2009) further noticed that I. nicoleti from the Bathonian of England and France, occurred only 403 in shallow-water sediments, represented by low-energy, inner muddy shelf and outer lagoon,

404

405

406

407

408

409

410

411

412

413

414

415

416

417

418

419

420

421

422

423

424

425

426

427

428 oolitic high-energy shoal system, carbonate/muddy low-energy, marine lagoon complex and in the shallow subtidal zone. All these are actually consistent with our own observations that indicates I. nicoleti (Tables 2 and 3) occurred in both carbonate and siliciclastic rocks, although it preferred shallow-water carbonates. Hunter \& Underwood (2009) concluded that the distribution of crinoids corresponds quite nicely to particular facies (but see also the comment on this paper by Salamon et al., 2010). This substrate-dependence is also corroborated by the ANOVA test (although at the generic-level) that the crinoid distribution is highly sensitive for carbonates (limestones) as opposed to siliciclastics (Table 5a-b).

Of interest is the observation on Pentacrinites dargniesi. Hunter \& Underwood (2009) also collected $P$. cf. dargniesi from shallow, muddy and carbonate habitats. $P$. dargniesi, despite being predominantly found in carbonates, also occurs in offshore claystones of Poland (see Table 2 and 3). Contextually, it must be keep in mind that $P$. dargniesi was a pseudo-planktonic crinoid that transported on the lower surfaces of driftwood fragments, and hence, is likely to occur in varied facies (see Simms, 1999; Hess, 1999a).

The most numerous isocrinids within the Middle Jurassic of Poland are balanocrinids (Balanocrinus subteres and B. pentagonalis). Hess (2014a, b) argued that balanocrinids settled mostly on hardgrounds but they are also be found these in mudstone-dominated settings, possibly on swells of the fine-grained bottom. The largest species of the slender crinoid genus (viz., $B$. subteres) was reported from below storm wave-base (Hess \& Spichiger, 2001), where it thrived due to ample nutrient availability and well-oxygenated bottom waters (Hess, 2014a, b). Klikushin's (1992) noted, as also in the present study, that Balanocrrinus subteres is another most cosmopolitan Mesozoic crinoid species. It occurs in both carbonate and siliciclastic facies and in environments of varying depth, from near shore (close to a beach) to the open shelf, but usually below normal wave base (Table 3 and Fig. 2). This lack of palaeodepth-dependency (although at the generic-level) is also reflected in the ANOVA test that suggests that paleodepth 
429 played no or minor role in the distribution of crinoids (Table 5c-d), although very weak (low $\mathrm{p}$

430 value) significance is noted for near shore and shallow marine settings, as discussed above, also 431 (see Figs. 2 and Table 5).

432 On the other hand, Hunter \& Underwood (2009) concluded that the occurrences of

433 balanocrinids (Balanocrinus cf. subteres) were restricted to neritic mudstone facies and

434 brachiopod-rich limestones (i.e., within the offshore, low-energy shelf setting). Hunter \&

435 Underwood (2009) also noted that the comatulids show a wide range of distribution from

436 offshore, low-energy shelf up to oolitic high-energy shoal system. In the present study,

437 corroborating previous observations (e.g., Hunter \& Underwood, 2009) (see also Table 5c-d), the

438 comatulids are restricted to siliciclastic rocks of near shore, below wave-base settings (Table 3 439 and Fig. 2).

440 The cyrtocrinids are considered as suggestive of relatively deep-sea depths and with 441 carbonate facies association (e.g., Arendt, 1974; Hess, 1975; Žítt, 1973, 1974, 1975, 1978a-d, 442 1979a, b, 1982, 1983). According to Ausich et al. (1999 and references cited therein), the 443 cyrtocrinids prefer depths exceeding $100 \mathrm{~m}$. Recent cyrtocrinids such as Cyathidium foresti live 444 at depths ranging from 380 to $900 \mathrm{~m}$, and C. plantei lives at a depth of $200 \mathrm{~m}$ (Hess, 1999b).

445 Nevertheless, rare single reports also indicate their presence in shallow (and extremely shallow) 446 environments (e.g., Salamon \& Gorzelak, 2007; Salamon, 2019; Krajewski et al., 2020). From 447 the Jurassic Yátova Formation of Spain, Zamora et al. (2018) illustrated the spongiolithic facies 448 as having been deposited in relatively shallow and open platform areas with depths not 449 exceeding $60 \mathrm{~m}$, containing the following cyrtocrinid cups: Eugeniacrinites sp., Pilocrinus sp., 450 Gammarocrinites sp.; and a basal circlet of Tetracrinidae indet. that actually belongs to 451 Tetracrinus moniliformis (see fig. 9e in Zamora et al., 2018). In the current study, 452 Gammarocrinites sp., Pilocrinus moussoni and Tetracrinus moniliformis occur in carbonates of 453 near shore and shallow marine, to deeper sublittoral under storm influence to open shelf 454 environments.

455 The roveacrinids represented by the genus Saccocoma are exclusive to the shallow 456 marine Bathonian and/or Callovian carbonates of the Tatra Mountains and the Pieniny Klippen 457 Belt (Tethyan province). Kowal-Kasprzyk et al. (2020) mentioned saccocomids from the 458 Oxfordian-Kimmeridgian exotic clasts of the Outer Carpathians in southern Poland. 459 Matyszkiewicz $(1996,1997)$ mentioned Saccocoma-calciturbidites resting on the slope beds of 
460 Oxfordian cyanobacterial-sponge carbonate buildups formed in the Polish epicontinental basin

461 (for summary see Fig. 2).

462 The cyclocrinids are not considered in the present study due to their controversial

463 taxonomic assignment (e.g., Hess, 2008).

464 Thus, qualitatively (see Fig. 2) isocrinids and cyclocrinids occur in both carbonate and

465 siliciclastic rocks. The cyrtocrinids and roveacrinids occur within carbonate rocks, whereas the

466 comatulids are exclusive to siliciclastics. In terms of palaeodepth, most crinoid groups dominate

467 in shallow environments with the sole exception of cyrtocrinids, that are ubiquitous and occur in

468 both shallow (near shore and shallow marine) and slightly deeper (deeper sublittoral to open

469 shelf) settings. The occurrences of the cosmopolitan taxa, Chariocrinus andreae and

470 Balanocrinus subteres (isocrinids), is independent of both substrate type and paleodepth. This

471 qualitative inference (Fig. 2) is largely mirrored quantitatively, also (Table 5).

472 The quantitative analysis (Fig. 2 and Table 5) suggests that the distribution of crinoids

473 show a strong substrate-dependency (Hypothesis 1) (see Fig. 2 and Table 5) corroborating results

474 by Simms (1988) and Hunter \& Underwood (2009). The palaeodepth-dependency (Hypothesis 2)

475 did not yield significant results, although very weak (low $\mathrm{p}$ value) significance is noted for near

476 shore and shallow marine settings (Table 5), as also reflected in qualitative analysis (see Figs. 2).

477 Although it must be accepted that the quantitative analysis (Table 5) is genus-based.

478 Nevertheless, and until more species-based datasets are available, present quantitative analysis

479 (Table 5) should prove useful in better understanding crinoid diversity trends. These results have

480 important bearing on crinoid diversity studies and underline the importance of incorporating

481 substrate details (facies analysis) while inferring distribution patterns of crinoid species diversity

482 and paleobiogeography. A more rigorous and quantitative species-based analysis may enable to

483 better understand their varied distribution patterns.

484

485 Conclusion

486

487 Almost all Bathonian and Callovian crinoids recorded from Poland dominate in relatively

488 shallow environments. The only exception are cyrtocrinids, that are equally common in both

489 shallow and deeper settings. The most commonly recorded Isocrinids, occur frequently in both

490 carbonate and siliciclastic rocks. Cyrtocrinids also occur likewise, but dominate in carbonates.

Peer) reviewing PDF | (2021:03:59630:2:1:NEW 27 Jul 2021) 
491 Roveacrinids are exclusive to carbonates, whereas cyclocrinids occur in both carbonates and 492 siliciclastics. The comatulids occur exclusively in siliciclastics. The most cosmopolitan crinoids 493 are the isocrinids, Chariocrinus andreae and Balanocrinus subtrees, that occur both in carbonate 494 and siliciclastic rocks, and in shallow and open-shelf environments. Statistical analyses 495 (ANOVA) corroborate these qualitative inferences, and suggests that the distribution of crinoids 496 show strong substrate-dependency (Hypothesis 1) but not palaeodepth-dependency (Hypothesis 497 2), although statistical significance (albeit very weak; low p value) is noted for near shore and 498 shallow marine settings. A more exhaustive species-based analysis may enable to better 499 understand their varied distribution patterns.

500

501

\section{Corresponding author}

502

503

Correspondence to Mariusz A. Salamon

504

505

\section{Competing interests}

506

507

We declare we have no competing interests.

508

509

\section{Acknowledgements}

510

511 Many friends, colleagues and students from the University of Silesia in Katowice (Tomasz

512 Brachaniec, Przemysław Gorzelak, Jakub Jakubski, Rafał Lach, Mateusz Syncerz, Michał Zatoń, 513 and some more whose names we do not remember) had been contributing through help during

514 fieldworks and donating some crinoid specimens in years 2006-2020. Our reviewers (Aaron 515 Hunter, Pedro Monarrez and an anonymous one) are acknowledged for critically reviewing the 516 manuscript and providing constructive comments that considerably improved it. We also would 517 like to thank Tomasz Wrzołek (University of Silesia in Katowice) for preparing polished slabs 518 involved in the current study. We are also grateful to Alfred Uchman (Jagiellonian University) 519 and Michał Zatoń for sharing references and providing subsequent literature. SJ thanks Ahmed 520 Awad Abdelhady (Egypt) for confirming statistical results. Last but not least thanks go to Marcin 
521 Krajewski (AGH University of Science and Technology) for useful comments on the early draft 522 of this MS.

523

524

\section{References}

525

526

Arendt, Y.A., 1974. Morskie lilii. Tsirtokrinidy (Sea lilies, Cyrtocrinids). Trudy

527

528

Paleontologicheskego Instituta, Akademia Nauk SSSR 144, 251 pp.

Ausich, W.J., 2001, Echinoderm taphonomy. In: Jangoux, M., Lawrence, J.M. (eds.),

529

530

531

532

533

534

535

536

537

538

539

540

541

542

543

544

545

546

547

548

549

550

551

Ausich, W.I., Donovan, S.K., Hess, H., Simms, M.J., 1999. Fossil occurrence. In: Hess, H., Ausich, W.I., Brett, C.E., Simms, M.J. (eds), Fossil crinoids. Cambridge University Press, Cambridge, 41-49.

Bather, F.A., 1898. Pentacrinus, a name and its history. Natural Sciences, 12, 245-256.

Baumiller, T.K., Ausich, W.J. 1992. The broken-stick model as a null hypthesis for crinoid stalk taphonomy and as a guide to the distribution of connective tissue in fossils. Paleobiology, $18,288-298$.

Biese, W., 1935-37: Crinoidea jurassica I. In: Quenstedt, W. (ed.), Fossilium Catalogus, I. Animalia, pt. 70, 73, 76. W. Junk. s'Gravenhage, 739 pp.

Brand, U. 1986. Paleoenvironrnental analysis of Middle Jurassic (Callovian) ammonoids from Poland: trace elements and stable isotopes. Journal of Paleontology, 60, 293-301.

Brett, C.E., Moffat, H.A., Taylor, W.L., 1997. Echinoderm taphonomy, taphofacies and Lagerstätten. In: Waters, J.A., Maples, C.G. (eds), Geobiology of echinoderms 3. The Paleontological Society Papers, 147-190.

Dayczak-Calikowska, K., 1980. Crinoidea. In: Malinowska, L. (ed.), Budowa Geologiczna Polski. T. 3, Atlas skamieniałości przewodnik i charakterystycznych. Cz. 2b. Mezozoik, Jura. Wydawnictwa Geologiczne, Warszawa, 249 pp.

Dayczak-Calikowska, K., Moryc, W., 1988. Evolution of sedimentary basin and palaeotectonics of the Middle Jurassic in Poland. Kwartalnik Geologiczny, 32, 117-136.

Feldman-Olszewska, A., 2007. Jura środkowa. Analiza sedymentologiczna. In: Ciechocinek IG 2. Profile Głębokich Otworów Wiertniczych Państwowego Instytutu Geologicznego, 117, 54-65. 
552 Feldman-Olszewska, A., 2008. Wyniki badań sedymentologicznych utworów jury środkowej w 553 otworze wiertniczym Brześć Kujawski IG 2. In: Feldman-Olszewska, A. (ed.), Brześć 554 Kujawski IG 1, IG 2, IG 3. Profile Głębokich Otworów Wiertniczych Państwowego 555 Instytutu Geologicznego, 125, 151-154.

556 Feldman-Oolszewska, A., 2012a. Wyniki badań sedymentologicznych utworów jury środkowej 557 w wierceniu Wojszyce IG 3. In: Wojszyce IG 1/1a, Wojszyce IG 3, Wojszyce IG 4.

558

559

560

561

562

563

564

565

566

567

568

569

570

571

572

573

574

575

576

577

578

579

580 Profile Głębokich Otworów Wiertniczych Państwowego Instytutu Geologicznego, 137, 152-158.

Feldman-Olszewska, A., 2012b. Wyniki badań sedymentologicznych utworów jury środkowej w wierceniu Wojszyce IG 4. In: Wojszyce IG 1/1a, Wojszyce IG 3, Wojszyce IG 4. Profile Głębokich Otworów Wiertniczych Państwowego Instytutu Geologicznego, 137, 158-166.

Feldman-Olszewska, A., 2018. Jura. Litologia i stratygrafia. In: Pacześna J., Sobień K., eds), Siedliska IG 1. Profile Głębokich Otworów Wiertniczych Państwowego Instytutu Geologicznego, 149, 71-77.

Gedl, P., 2008. Dinoflagellate cysts from Callovian of Łuków (Poland) - a reexamination. Neues Jahrbuch für Geologie und Paläontologie, Abhandlungen, 247, 209-269.

Gedl, P., Kaim, A., Boczarowski, A., Kędzierski, M., Smoleń, J., Szczepanik, P., Witkowska, M., Ziaja, J., 2003. Rekonstrukcja paleośrodowiska sedymentacji środkowojurajskich iłów rudonośnych Gnaszyna (Częstochowa) - wyniki wstępne. Tomy Jurajskie, 1, 19-27.

Głuchowski, E., 1987. Jurassic and early Cretaceous Articulate Crinoidea from the Pieniny Klippen belt and the Tatra Mts, Poland. Studia Geologica Polonica 94, 6-102.

Gorzelak, P., Salamon, M.A., 2013. Experimental tumbling of echinoderms - taphonomic patterns and implications. Palaeogeography, Palaeoclimatology, Palaeoecology, 386, 569574.

Hallam, A. 1975. Jurassic Environments. Cambridge University Press, Cambridge, 269 pp.

Hess, H., 1972. Chariocrinus n. gen. für Isocrinus andreae Desor aus dem unteren Hauptrogenstein (Bajocien) des Basler Juras. Eclogae geologicae Helvetiae, 65, 197-210.

Hess, H., 1975. Die fossilen Echinodermen des Schweizer Juras. Veröffentlichungen aus dem Naturhistorischen Museum Basel 8, 130 pp. 
581 Hess, H., 1999a. Middle Jurassic of Northern Switzerland. In: Hess, H., Ausich, W.I., Brett, 582 C.E., Simms, M.J. (eds), Fossil Crinoids. Cambridge University Press, Cambridge, 203$583 \quad 215$.

584 Hess, H., 1999b. Recent. In: Hess, H., Ausich, W.I., Brett, C.E., Simms, M.J. (eds), Fossil 585 Crinoids. Cambridge University Press, Cambridge, 237-244.

586 Hess, H., 2006. Crinoids (Echinodermata) from the Lower Jurassic (Upper Pliensbachian) of 587 Arzo, southern Switzerland. Schweizerische Paläontologische Abhandlungen 126, 1-144.

588 Hess, H., 2008. Cyclocrinus, an enigmatic Jurassic-Cretaceous crinoid. Swiss journal of 589 Geoscience, DOI 10.1007/s00015-008-1273-1.

590 Hess, H., 2014a. Balanocrinus and other crinoids from Late Jurassic mudstones of France and 591 Switzerland. Swiss Journal of Palaeontology 133, 47-75.

592 Hess, H., 2014b. Balanocrinus (Crinoidea) from the Jurassic: species concept, reconstruction, 593 ontogeny, taphonomy and ecology. Swiss Journal of Palaeontology 133, 35-45.

594 Hess, H., Messing, C.G., 2011. Treatise on Invertebrate Paleontology, part T, Echinodermata 2, 595 Crinoidea 3. The University of Kansas, Paleontological Institute, Lawrence, 261 pp. 596 Hess, H., Salamon, M.A., Gorzelak, P., 2011. Late Jurassic-Early Cretaceous (Tithonian597 598 599 600 601 602 603 604 605 606 607 608 609 Berriasian) cyrtocrinids from south-eastern Poland. Neues Jahrbuch für Geologie und Paläontologie, Abhandlungen 260, 119-128.

Hess, H., Spichiger, U., 2001. Argoviacrinus rarissimus n. g. n. sp., a new crinoid (Echinodermata) from the Middle Oxfordian of Northern Switzerland. Eclogae geologicae Helvetiae, 94, 489-494.

Hunter, A.W., Underwood, C.J., 2009. Palaeoenvironmental control on distribution of crinoids in the Bathonian (Middle Jurassic) of England and France. Acta Palaeontologica Polonica, $54,77-98$.

Hunter, A.W., Underwood, C.J., 2010. Comment and reply on "Palaeoenvironmental control on distribution of crinoids in the Bathonian (Middle Jurassic) of England and France" by Aaron W. Hunter and Charlie J. Underwood. Acta Palaeontologica Polonica, 55, 174-176.

Kaim, A., 2004. The evolution of conch ontogeny in Mesozoic open marine gastropods. Acta Palaeontologica Polonica, 62, 1-183.

Klikushin, V.G., 1992. Iskopaemye morskie lilii pentakrinidy i ikh rasprostranenie v SSSR. Leningrad Palaeontological Laboratory, Sankt Petersburg, 358 pp. 
612 Knaust, D., Bromley, R.G. (editors), 2012. Trace fossils as indicators of sedimentary 613 environments, Developments in Sedimentology 64, Elsevier, 924 pp.

614 Kopik J., 1974 - Genus Cadomites Munier-Chalmas, 1892 (Ammonitina) in the Upper Bajocian 615 and Bathonian of the Cracow-Wielun Jurassic range and the Góry Świętokrzyskie 616 Mountains (Southern Poland). Biuletyn IG 276: 7-53.

617 Kopik, J., 1976. O przedstawicielach rodzin Phylloceratidae Zittel, 1884, Haploceratidae Zittel, 6181884 i Oppeliidae Bonarelli, 1894 (Ammonoidea) w keloweju jury częstochowskiej. 619 Biuletyn Instytutu Geologicznego, 295, 109-136.

620 Kopik, J., 1979a. Callovian of the Częstochowa Jura (South-Western Poland). Prace Instytutu 621 Geologicznego, 93, 1-52.

622 Kopik, J., 1979b. Stratygrafia jury środkowej regionu bełchatowskiego. Kwartalnik 623 Geologiczny, 23, 179-194.

624 Kopik, J., 1998. Jura dolna i środkowa północno-wschodniego obrzeżenia Górnośląskiego 625 Zagłębia Węglowego. Biuletyn Państwowego Intytutu Geologicznego, 378, 67-120. 626 Kopik, J., 2006. Bathonian ammonites of the families Sphaeroceratidae Buckman and Tulitidae Buckman from the Polish Jura Chain (Southern Poland). Polish Geological Institute Special Papers, 21, 1-68.

Kowal-Kasprzyk, J., Krajewski, M., Gedl, P., 2020. The oldest stage of the Outer Carpathian 630 evolution in the light of Oxfordian-Kimmeridgian exotic clast studies (southern Poland). Facies, 66, 11.

Krajewski, M., Olchowy, P., Salamon, M.A., 2019. Late Jurassic (Kimmeridgian) sea lilies (Crinoidea) from central Poland (Łódź Depression). Annales de Paléontologie, 105, 63-73.

Krajewski, M., Ferré, B., Salamon, M.A., 2020. Cyrtocrinids (Cyrtocrinida, Crinoidea) and other associated crinoids from the Jurassic (Kimmeridgian-Tithonian)-Cretaceous (BerriasianBarremian) of the Carpathian Foredeep basement (western Ukraine). Geobios, 60, 61-77.

Krajewski, M., Olchowy, Felisiak, I., 2016. Late Jurassic facies architecture of the Złoczew Graben: implications for evolution of the tectonic-controlled northern peri-Tethyan shelf (Upper Oxfordian-Lower Kimmeridgian, Poland). Facies, 62, 1-19. Société Paléontologique Suisse, 4, 1-52; 5, 3-124; 6, 125-300. 
642 Makowski, H., 1952. La faune Callovienne de Łuków en Pologne. Palaeontologia Polonica, 4, 1643 62.

644

645

646

647

648

649

650

651

652

653

654

655

656

657

658

659

660

661

662

663

664

665

666

667

668

669

670

671

672

Marynowski, L., Philippe, M., Zatoń, M., Hautevelle, Y., 2008. Systematic relationships of the Mesozoic wood genus Xenoxylon: an integrative biomolecular and palaeobotanical approach. Neues Jahrbuch für Geologie und Paläontologie, Abhandlungen, 247, 177-189.

Matyja, B.A., Wierzbowski, A., 2000. Ammonites and stratigraphy of the uppermost Bajocian and Lower Bathonian between Częstochowa and Wieluń, Central Poland. Acta Geologica Polonica, 50, 191-209.

Matyja, B.A., Wierzbowski, A. 2003. Biostratygrafia amonitowa formacji częstochowskich iłów rudonośnych (najwyższy bajos-górny baton) z odsłonięcia w Częstochowie. Tomy Jurajskie, 1, 3-6.

Matyszkiewicz, J., 1996. The significance of Saccocoma-calciturbidites for the analysis of the polish epicontinental late Jurassic bas. An example from the Southern Cracow-Wielun Upland (Poland). Facies, 34, 23-40.

Matyszkiewicz, J., 1997. Microfacies, sedimentation and some aspects of diagenesis of Upper Jurassic sediments from the elevated part ofthe Northern peri-Tethyan Shelf: a comparative study on the Lochen area (Schwäbische Alb) and the Cracow area (CracowWieluń Upland, Poland). Berliner Geowissenschaftliche Abhandlungen E21, 1-111.

Messing, C.G., 1985. Submersible observations of deep-water crinoid assemblages in the tropical western Atlantic Ocean. In: Keegan, B.F. \& O'Connor, B.D.S. (eds), Proceedings of the 5th International Echinoderm Conference. Galway, Balkema, 185-193.

Messing, C.G., 2008. A new species of five-armed feather star, Pentametrocrinus paucispinulus n. sp., from the eastern Pacific (Echinodermata: Crinoidea: Comatulida). Proceedings of the Biological Society of Washington, 121, 269-275.

Mizerski, W., Szamałek, K., 1985. Charakterystyka geologiczno-surowcowa kelowejskich skał ilastych kry lodowcowej w rejonie Gołaszyna k. Łukowa. Kwartalnik Geologiczny, 29, 369-392.

Niemczycka, T., 1965. Boundary of the Middle and Uplper Jurassic in the northern area of the Lublin region and in the Podlasie region. Geological Quarterly, 9, 603-615.

Niemczycka T., 1979 - Litho- and biostratigraphic boundary of the Middle and UpperJurassic in southern Podlasie. Geological Quarterly, 23, 803-817. 
673 Olempska, E., Błaszyk, J., 2001. A boreal ostracod assemblage from the Callovian of the Łuków 674 area, Poland. Acta Palaeontologica Polonica, 46, 553-582.

675 Pieńkowski, G., Schudack, M.E. (Coordinators), Bosák, P., Enay, R., Feldman-Olszewska, A., 676 Golonka, J., Gutowski, J., Herngreen, G.F.W., Jordan, P., Krobicki, M., Lathuiliere, B., 677 Leinfelder, R.R., Michalík, J., Mönnig, E., Noe-Nygaard, N., Pálfy, J., Pint, A., Rasser, 678 M.W., Reisdorf, A., Schmid, D.U., Schweigert, G., Surlyk, F., Wetzel, A., Wong, T.E., 679 2008. Jurassic. In: McCann, T. (ed.), The Geology of Central Europe. Vol. 2: Mesozoic 680 and Cenozoic. The Geologfical Society, London. 823-922.

681 Radwańska, U., 2005. Lower Kimmeridgian comatulid crinoids of the Holy Cross Mountains, 682 Central Poland. Acta Geologica Polonica, 55, 269-282.

683 Radwańska, U., Radwański, A., 2003. The Jurassic crinoid genus Cyclocrinus d'Orbigny, 1850: 684 still an enigma. Acta Geologica Polonica, 53, 301-320.

685 Różycki, S.Z., 1953. Górny dogger i dolny malm Jury Krakowsko-Częstochowskiej. Prace $686 \quad$ Instytutu Geologicznego, 17, 1-412.

687 Salamon, M.A., 2008a. The Callovian (Middle Jurassic) crinoids from the black clays of the 688 Łuków area, eastern Poland. Neues Jahrbuch für Geologie und Paläontologie, 689 Abhandlungen 247, 133-146.

690 Salamon, M.A., 2008b. Jurassic cyrtocrinids (Cyrtocrinida, Crinoidea) from extra-Carpathian 691 Poland. Palaeontographica Abt. A 285, 77-99.

692 Salamon, M.A., 2008c. The Callovian (Middle Jurassic) crinoids from northern Lithuania. 693 Paläontologische Zeitschrift 82, 269-278.

694 Salamon, M.A., 2009. Early Cretaceous (Valanginian) sea lilies (Echinodermata, Crinoidea) 695 from Poland. Swiss journal of Geosciences, 102, 77-88.

696 Salamon, M.A., 2019. A new prospect in crinoid (Crinoidea, Echinodermata) research: An 697 example from the Lower Jurassic of Montenegro [Une nouvelle perspective dans l'étude 698 des crinoïdes (Crinoidea, Echinodermata): Un exemple du Jurassique inférieur du 699 Monténégro]. Carnets de Geologie, 19, 211-220.

700 Salamon, M.A., Feldman-Olszewska, A., 2018. Crinoids (Crinoidea, Echinodermata) from the 701 Middle Jurassic (Callovian) of eastern Poland: A case study from the Żebrak IG1 702 Borehole. Annales Societatis Geologorum Poloniae 88, 273-283. 
703

704

705

706

707

708

709

710

711

712

713

714

715

716

717

718

719

720

721

722

723

724

725

726

727

728

729

730

731

732

Salamon, M.A., Gorzelak, P., 2007. Evidence of shallow-water cyrtocrinids (Crinoidea) from the Callovian of Poland. Neues Jahrbuch für Geologie und Paläontologie, Abhandlungen 244, $257-260$.

Salamon, M.A., Gorzelak, P., 2010. Cyrtocrinids (Echinodermata, Crinoidea) from Upper Jurassic Štramberk-type limestones in southern Poland. Palaeontology, 53, 869-885.

Salamon, M.A., Zatoń, M., 2006. Balanocrinus hessi, a new crinoid (Echinodermata) from the Callovian (Middle Jurassic) of southern Poland. Neues Jahrbuch für Geologie und Paläontologie, Abhandlungen, 240, 1-17.

Salamon, M.A., Gorzelak, P., Zatoń, M., 2010. Comment on "Palaeoenvironmental control on distribution of crinoids in the Bathonian (Middle Jurassic) of England and France" by Aaron W. Hunter and Charlie J. Underwood. Acta Palaeontologica Polonica, 55, 172-173.

Salamon, M.A., Zatoń, M., 2007. Late Bajocian trough Callovian (Middle Jurassic) crinoid fauna from the epicontinental deposits of Poland. Swiss journal of Geosciences, 100, 153-164.

Simms, M. J., 1989. British Lower Jurassic crinoids. The Palaeontological Society, London, $102 \mathrm{pp}$.

Simms, M. J., 1999. Pentacrinites from the Lower Jurassic of Dorset Coast of Southern England. In: Hess, H., Ausich, W.I., Brett, C.E., Simms, M.J. (eds), Fossil Crinoids. Cambridge University Press, Cambridge, 177-182.

Šimkevičius, P., Ahlberg, A., Grigelis, A., 2003. Jurassic smectite and kaolinite trends of the East European Platform: implications for palaeobathymetry and palaeoclimate. Terra Nova, 15, 225-229.

Tang, C.M., Bottjer, D.J., Simms, M.J., 2000. Stalked crinoids from a Jurassic deposit in western North America. Lethaia, 33, 46-54.

Ubaghs, G., 1953. Sous-Classe 4. Articulata J. S. Miller. In: Piveteau, J. (Ed.), Traité de Paléontologie, 3. Masson, Paris, 756-765.

Villier, L., 2008. Sea star ossicles from the Callovian black clays of the Łuków area, eastern Poland. Neues Jahrbuch für Geologie und Paläontologie, Abhandlungen, 247, 147-160.

Wójcik, K., 1910. Bat, kelowej i oxford okręgu krakowskiego (stratygrafia). Rozprawy Wydziału Matematyczno-Przyrodniczego Akademii Umiejętności w Krakowie, Seria B, $50,409-511$. 
733

734

735

736

737

738

739

740

741

742

743

744

745

746

747

748

749

750

751

752

753

754

755

756

757

758

759

760

761

Zamora, S., Aurell, M., Veitch, M., Saulsbury, J., López-Horgue, M.A., Ferratges, F.A., Arz, J.A., Baumiller, T.K., 2018. Environmental distribution of post-Palaeozoic crinoids from the Iberian and south-Pyrenean basins, NE Spain. Acta Palaeontologica Polonica, 63, 779794.

Zatoń, M., 2010. Bajocian-Bathonian (Middle Jurassic) ammonites from the Polish Jura. Part 1: Families Phylloceratidae, Nannolytoceratidae, Sonniniidae, Strigoceratidae, Oppeliidae and Lissoceratidae. Palaeontographica, Abt. A, 292, 65-113.

Zatoń, M., 2010. Bajocian-Bathonian (Middle Jurassic) ammonites from the Polish Jura. Part 2: Families Stephanoceratidae, Perisphinctidae, Parkinsoniidae, Morphoceratidae and Tulitidae. Palaeontographica, Abt. A, 292, 115-213.

Zatoń, M., Barbacka, M., Marynowski, L., Krzystanek, J., 2006b. Sagenopteris (Caytoniales) with its possible preserved biomarkers from the Bathonian of the Polish Jura, southcentral Poland. Neues Jahrbuch für Geologie und Paläontologie, Monatshefte, 7, 385402.

Zatoń, M., Marynowski, L., 2004. Konzentrat-Lagerstatte - type carbonate concretions from the uppermost Bajocian (Middle Jurassic) of the Częstochowa area, South-Central Poland. Geological Quarterly, 48, 339-350.

Zatoń, M., Marynowski, L., 2006. Ammonite fauna from uppermost Bajocian (Middle Jurassic) calcitic concretions from the Polish Jura - biogeographical and taphonomical implications. Geobios, 39, 426-442.

Zatoń, M., Marynowski, L., Bzowska, G., 2006a. Konkrecje hiatusowe z iłów rudonośnych Wyżyny Krakowsko-Częstochowskiej (Jura Polska). Przegląd Geologiczny, 54, 131-138.

Zatoń, M., Villier, L., Salamon, M.A., 2007. Signs of predation in the Middle Jurassic of southcentral Poland: evidence from echinoderm taphonomy. Lethaia, 40, 139-151.

Zatoń, M., Wilson, M.A., Zavar, E., 2011. Diverse sclerozoan assemblages encrusting large bivalve shells from the Callovian (Middle Jurassic) of southern Poland. Palaeogeography, Palaeoclimatology, Palaeoecology, 307, 232-244.

Žítt, J., 1973. Entoneutral system of the Sclerocrinus. Věstník Ústředního ústavu geologického $48,25-29$. 
762 Žítt, J., 1974. Sclerocrinus Jaekel, 1891 and Proholopus Jaekel, 1907 (Crinoidea, Cyrtocrinida)

763 from the Lower Cretaceous of Štramberk (Czechoslovakia). Sborník geologických Věd, 764 Paleontologie 16, 7-32.

765 Žítt, J., 1975. Sclerocrinus kotoucensis sp. n. (Cyrtocrinida, Crinoidea) from the Lower 766 Cretaceous of Štramberk (Czechoslovakia). Věstník Ústředního ústavu geologického 50, 767 115-117.

768

769

770

771

772

773

774

775

776

777

778

779

780

781

782

783

784

785

786

787

788

789

790

791

792

Žítt, J., 1978a. Deformations of Phyllocrinus malbosianus d'Orbigny from Štramberk (Czechoslovakia). Časopis pro mineralogii a geologii 23, 277-284.

Žítt, J., 1978b. Phyllocrinus d'Orbigny, 1850 (Crinoidea, Cyrtocrinida) from the Lower Cretaceous of Štramberk (Czechoslovakia). Časopis pro mineralogii a geologii 23, 39-58.

Žitt, J., 1978c. Phyllocrinid microcrinoids (Cyrtocrinida) from the Lower Cretaceous of Štramberk (Czechoslovakia). Věstník Ústředního ústavu geologického 53, 145-151.

Žítt, J., 1978d. Apsidocrinus Jaekel and Psalidocrinus Remeš (Crinoidea, Cyrtocrinida) from the Lower Cretaceous of Štramberk (Czechoslovakia). Sborník geologických Věd, Paleontologie 21, 107-124.

Žítt, J., 1979a. Hemibrachiocrinidae Arendt, 1968 (Crinoidea, Cyrtocrinida) from the Lower Cretaceous of Štramberk (Czechoslovakia). Věstník Ústředního ústavu geologického, 54, 341-348.

Žitt, J., 1979b. Strambergocrinus gen. n. (Cyrtocrinida) from the Lower Cretaceous of Štramberk (Czechoslovakia). Časopis pro mineralogii a geologii 24, 237-247.

Žítt, J., 1982. A new type of stem in Eugeniacrinites. Acta Universitatis Carolinae-Geologica 4, 409-420.

Žítt, J., 1983. Spoon-like crinoids from Štramberk (Lower Cretaceous, ČSSR). Sborník Národního Muzea v Praze 39B, 69-114.

\section{Figure captions:}

Figure 1. A. Palaeogeographic map of central Europe during the Middle Jurassic (modified after Šimkevičius et al., 2003). A- Bathonian and Callovian exposures of the southern part of the Polish Jura; B - Bathonian and Callovian exposures of the southern margin of the Holy Cross Mountains; C - Callovian exposure of the glacial drift in Łuków; G1-G6 - location of the 
793 Bathonian-Callovian boreholes described in this constribution [Tłuszcz IG 1 (G1), Siedliska IG 1 794 (G2), Kock IG 2 (G3), Żyrzyn IG 1 (G4), Maciejowice IG 1 (G5), Magnuszew IG1 (G6)], D

795 location of borehole Żebrak IG 1 (details in Salamon \& Feldman-Olszewska, 2018); A-D -

796 Central European province; E - Bathonian and Callovian exposures of the Tatra Mountains; F -

797 Bathonian and Callovian exposures of the Pieniny Klippen Belt; E, F - Tethyan province B. Map

798 of Callovian lithofacies noted in Poland (modified after Dayczak-Calikowska \& Moryc, 1988).

799

800 Figure 2. Model showing distribution of selected Callovian crinoids.

801

802

Figure 3. Cyclocrinid remains from southern Poland. A. Columnal, articular facet. B. Brachial 803 plate. Scale bar equals $1 \mathrm{~mm}$. Blue arrows mark granules covering the articular facet of 804 columnal.

805

806

\section{Table captions:}

807

808

Table 1. Bathonian-Callovian crinoids collected in particular boreholes in eastern Poland.

Table 2. Bathonian and Callovian crinoid list recorded in different areas of Poland.

810 Table 3. Distribution of Bathonian-Callovian crinoids recorded in Poland within different facies 811 and settings.

812 Table 4. Number of collected crinoid remains during observation of respective cores and 813 maceration process.

814 Table 5. Analysis Of Variance (ANOVA). a. ANOVA test between different substrate types

815 (Claystones, Sandstones and Limestones). b. Tukey's HSD (honestly significant difference) test 816 for pairwise comparisons. c. ANOVA test between different paleodepth parameters (Near shore, 817 Shallow-marine, Mid-ramp and Off shore). d. Tukey's HSD (honestly significant difference) test 818 for pairwise comparisons. 


\section{Table 1 (on next page)}

Bathonian-Callovian crinoids collected in particular boreholes in eastern Poland. 


\begin{tabular}{|c|c|c|c|c|}
\hline Borehole & $\begin{array}{l}\text { Depth } \\
\text { (in } \mathbf{m} \text { ) }\end{array}$ & Age & Lithology & $\begin{array}{c}\text { determinable crinoid } \\
\text { taxa }\end{array}$ \\
\hline Kock IG 2 & 859.0 & Callovian? & $\begin{array}{l}\text { Yellowish grey, crinoidal } \\
\text { limestone, packstone composed } \\
\text { of echinoderm plates, bivalve } \\
\text { shells, rare bryozoa fragments } \\
\text { with ferruginous impregnations, } \\
\text { ferruginous ooids, rounded quartz } \\
\text { grains and sparite cement. }\end{array}$ & $\begin{array}{l}\text { Isocrinida indet. } \\
\text { Balanocrinus subteres }\end{array}$ \\
\hline $\begin{array}{l}\text { Maciejowice } \\
\text { IG } 1\end{array}$ & $1,431.5$ & late Bathonian & $\begin{array}{l}\text { Dark grey, medium-size } \\
\text { sandstone }\end{array}$ & none \\
\hline \multirow{4}{*}{ Magnuszew IG 1} & $1,505.7$ & late Callovian & $\begin{array}{l}\text { Yellowish grey, crinoidal } \\
\text { limestone, grainstone composed } \\
\text { of echinoderm plates, echinoid } \\
\text { spines, rounded quartz grains, } \\
\text { sparite cement and iron } \\
\text { oxides/hydroxides }\end{array}$ & $\begin{array}{l}\text { Isocrinida indet. } \\
\text { Balanocrinus subteres } \\
\text { Pentacrinites dargniesi }\end{array}$ \\
\hline & $1,507.3$ & late Callovian & $\begin{array}{l}\text { Yellowish grey, crinoidal } \\
\text { limestone with amonite and } \\
\text { belemnite, grainstone composed } \\
\text { of echinoderm plates, echinoid } \\
\text { spines, bivalve shells, rounded } \\
\text { quartz grains, sparite cement and } \\
\text { iron oxides/hydroxides }\end{array}$ & $\begin{array}{c}\text { Isocrinida indet. } \\
\text { Pentacrinites dargniesi }\end{array}$ \\
\hline & $1,508.65$ & late Callovian & $\begin{array}{l}\text { Grey crinoidal limestone, } \\
\text { grainstone composed of } \\
\text { echinoderm plates, echinoid } \\
\text { spines, bivalve shells, bryozoa } \\
\text { fragments, rare gastropoda, } \\
\text { rounded quartz grains and sparite } \\
\text { cement }\end{array}$ & $\begin{array}{l}\text { Isocrinida indet. } \\
\text { Balanocrinus subteres } \\
\text { Pentacrinites dargniesi }\end{array}$ \\
\hline & $1,522.4$ & $\begin{array}{l}\text { middle-late } \\
\text { Callovian }\end{array}$ & $\begin{array}{l}\text { Yellow-brown, dolomitic } \\
\text { crinoidal limestone with } \\
\text { foraminifera, quartz grains and } \\
\text { iron oxides/hydroxides }\end{array}$ & $\begin{array}{c}\text { Isocrinida indet. } \\
\text { Isocrinus nicoleti } \\
\text { Balanocrinus subteres } \\
\text { Balanocrinus pentagonalis } \\
\text { Pentacrinites dargniesi }\end{array}$ \\
\hline \multirow{3}{*}{ Siedliska IG 1} & 824.65 & early Callovian & $\begin{array}{l}\text { Beige-grey, crinoidal limestone, } \\
\text { grainstone composed of } \\
\text { echinoderm plates, echinoid } \\
\text { spines and bryozoa fragments } \\
\text { frequently with ferruginous } \\
\text { impregnations, crushed bivalve } \\
\text { and bryozoa shells, gastropods, } \\
\text { lithoclasts with iron hydroxides, } \\
\text { rare ferruginous ooids, quartz } \\
\text { grains, sparite or sparite-micrite } \\
\text { cement and iron } \\
\text { oxides/hydroxides }\end{array}$ & $\begin{array}{c}\text { Isocrinida indet. } \\
\text { Pentacrinites dargniesi }\end{array}$ \\
\hline & 828.25 & early Callovian & $\begin{array}{l}\text { Beige-grey, crinoidal } \\
\text { limestonegrainstone composed of } \\
\text { echinoderm plates, echinoid } \\
\text { spines and bryozoa fragments } \\
\text { frequently with ferruginous } \\
\text { impregnations, crushed bivalve } \\
\text { and bryozoa shells, gastropods, } \\
\text { lithoclasts with iron hydroxides, } \\
\text { rare ferruginous ooids, quartz } \\
\text { grains, sparite or sparite-micrite } \\
\text { cement and iron } \\
\text { oxides/hydroxides }\end{array}$ & $\begin{array}{l}\text { Isocrinida indet. } \\
\text { Balanocrinus subteres } \\
\text { Pentacrinites dargniesi }\end{array}$ \\
\hline & 828.77 & early Callovian & Beige-grey, crinoidal limestone & Isocrinida indet. \\
\hline
\end{tabular}




\begin{tabular}{|c|c|c|c|c|}
\hline & & & $\begin{array}{l}\text { grainstone composed of } \\
\text { echinoderm plates, echinoid } \\
\text { spines and bryozoa fragments } \\
\text { frequently with ferruginous } \\
\text { impregnations, crushed bivalve } \\
\text { and bryozoa shells, gastropods, } \\
\text { lithoclasts with iron hydroxides, } \\
\text { rare ferruginous ooids, quartz } \\
\text { grains, sparite or sparite-micrite } \\
\text { cement and iron } \\
\text { oxides/hydroxides }\end{array}$ & $\begin{array}{l}\text { Isocrinus nicoleti } \\
\text { Balanocrinus subteres } \\
\text { Pentacrinites dargniesi } \\
\text { Cyrtocrinida indet. }\end{array}$ \\
\hline & 830.8 & late Bathonian? & $\begin{array}{c}\text { Yellow-brown, crinoidal } \\
\text { limestone with abundant iron } \\
\text { hydroxides, lithoclasts and } \\
\text { bivalve shells. }\end{array}$ & none \\
\hline & 837.65 & late Bathonian? & $\begin{array}{l}\text { Yellow crinoidal limestone, } \\
\text { grainstone composed of } \\
\text { echinoderm plates, echinoid } \\
\text { spines and bryozoa fragments } \\
\text { frequently with ferruginous } \\
\text { impregnations, crushed bivalve } \\
\text { and bryozoa shells, gastropods, } \\
\text { lithoclasts with iron hydroxides, } \\
\text { rare ferruginous ooids, quartz } \\
\text { grains, sparite or sparite-micrite } \\
\text { cement and iron } \\
\text { oxides/hydroxides }\end{array}$ & $\begin{array}{c}\text { Isocrinida indet. } \\
\text { Chariocrinus andreae } \\
\text { Balanocrinus subteres } \\
\text { Balanocrinus pentagonalis } \\
\text { Pentacrinites dargniesi }\end{array}$ \\
\hline \multirow[b]{2}{*}{ Tłuszcz IG 1} & $1,047.7$ & $\begin{array}{l}\text { late Callovian?- } \\
\text { early Oxfordian }\end{array}$ & Beige-grey, crinoidal limestone & none \\
\hline & $1,049.95$ & late Callovian & $\begin{array}{c}\text { Cream crinoidal limestone, } \\
\text { grainstone composed of } \\
\text { echinoderm plates, echinoid } \\
\text { spines and bryozoa fragments, } \\
\text { bivalve shells, very rare } \\
\text { foraminifera, sparite cement and } \\
\text { iron oxides/hydroxides } \\
\end{array}$ & $\begin{array}{c}\text { Isocrinida indet. } \\
\text { Balanocrinus pentagonalis } \\
\text { Pentacrinites dargniesi } \\
\text { Phyllocrinus } \mathrm{sp} .\end{array}$ \\
\hline \multirow{4}{*}{ Żyrzyn IG 1} & $1,134.95$ & Callovian & $\begin{array}{c}\text { Yellowish grey, crinoidal } \\
\text { limestone, grainstone composed } \\
\text { of echinoderm plates, bryozoa } \\
\text { fragments, bivalve shells, quartz } \\
\text { grains, sparite cement and iron } \\
\text { oxides/hydroxides }\end{array}$ & $\begin{array}{l}\text { Isocrinida indet. } \\
\text { Chariocrinus andreae } \\
\text { Pentacrinites dargniesi } \\
\text { Cyrtocrinida indet. }\end{array}$ \\
\hline & $1,137.7$ & late Bathonian? & $\begin{array}{l}\text { Beige-grey, crinoidal limestone } \\
\text { with cement and iron hydroxides }\end{array}$ & none \\
\hline & $1,147.9$ & late Bathonian & $\begin{array}{l}\text { Beige-grey, crinoidal limestone } \\
\text { grainstone composed of } \\
\text { echinoderm plates, echinoid } \\
\text { spines, bryozoa fragments, } \\
\text { bivalve and brachiopods shells, } \\
\text { quartz grains, sparite cement and } \\
\text { iron oxides/hydroxides }\end{array}$ & $\begin{array}{l}\text { Isocrinida indet. } \\
\text { Isocrinus nicoleti } \\
\text { Chariocrinus andreae } \\
\text { Balanocrinus subteres } \\
\text { Pentacrinites dargniesi } \\
\text { Cyrtocrinida indet. }\end{array}$ \\
\hline & $1,155.4$ & late Bathonian & $\begin{array}{l}\text { Yellow-brown, crinoidal } \\
\text { limestone, grainstone composed } \\
\text { of echinoderm plates, bryozoa } \\
\text { fragments, bivalve and } \\
\text { brachiopods shells, sparite cement } \\
\text { and iron oxides/hydroxides }\end{array}$ & $\begin{array}{c}\text { Isocrinida indet. } \\
\text { Isocrinus nicoleti } \\
\text { Balanocrinus pentagonalis } \\
\text { Pentacrinites dargniesi }\end{array}$ \\
\hline
\end{tabular}


Table 2 (on next page)

Bathonian and Callovian crinoid list recorded in different areas of Poland. 


\begin{tabular}{|c|c|c|c|}
\hline $\begin{array}{l}\text { Location area } \\
\text { (see also details in } \\
\text { Fig. } 1 \text { and its } \\
\text { caption) }\end{array}$ & Age & Number of crinoid taxa & List of crinoids \\
\hline $\begin{array}{l}\text { A - glacial drift in } \\
\text { Łuków; Central } \\
\text { European province }\end{array}$ & Callovian & $\begin{array}{l}\text { 10, including: } \\
8 \text { isocrinids and } 2 \text { comatulids }\end{array}$ & $\begin{array}{c}\text { Isocrinids: } \\
\text { Chariocrinus andreae } \\
\text { Balanocrinus berchteni } \\
\text { Balanocrinus pentagonalis } \\
\text { Balanocrinus subteres } \\
\text { Isocrinus } \text { sp. } \\
\text { Isocrinus nicoleti } \\
\text { Isocrinus pendulus } \\
\text { Pentacrinites } \text { cf. dargniesi } \\
\text { Comatulids: } \\
\text { Paracomatulidae sp. et gen. indet. } \\
\text { Palaeocomaster } \text { sp. }\end{array}$ \\
\hline $\begin{array}{l}\text { B - boreholes in } \\
\text { eastern Poland (Kock } \\
\text { IG 2, Maciejowice } \\
\text { IG 1, Magnuszew IG } \\
\text { 1, Siedliska IG 1, } \\
\text { Thuszcz IG 1, Żyrzyn } \\
\text { IG 1); Central } \\
\text { European province }\end{array}$ & $\begin{array}{l}\text { latest } \\
\text { Bathonian- } \\
\text { Callovian }\end{array}$ & $\begin{array}{l}8, \text { including: } \\
6 \text { isocrinids and } 2 \text { cyrtocrinids }\end{array}$ & $\begin{array}{c}\text { isocrinids: } \\
\text { Isocrinida indet. } \\
\text { Chariocrinus andreae } \\
\text { Balanocrinus subteres } \\
\text { Balanocrinus pentagonalis } \\
\text { Isocrinus nicoleti } \\
\text { Pentacrinites dargniesi } \\
\text { Cyrtocrinids: } \\
\text { Cyrtocrinida indet. } \\
\text { Phyllocrinus } \text { sp. }\end{array}$ \\
\hline $\begin{array}{l}\text { B - Żebrak IG 1; } \\
\text { Central European } \\
\text { province }\end{array}$ & Callovian & $\begin{array}{l}\text { 6, including: } \\
5 \text { isocrinids and } 1 \text { cyrtocrinid }\end{array}$ & $\begin{array}{c}\text { isocrinids: } \\
\text { Chariocrinus andreae } \\
\text { Balanocrinus } \text { cf. subteres } \\
\text { Isocrinus } \text { sp. } \\
\text { Isocrinus } \text { cf. nicoleti } \\
\text { Pentacrinites } \text { sp. } \\
\text { Cyrtocrinids: } \\
\text { Cyrtocrinida indet. }\end{array}$ \\
\hline $\begin{array}{l}\mathrm{C} \text { - southern margin } \\
\text { of the Holy Cross } \\
\text { Mountains; Central } \\
\text { European province }\end{array}$ & Bathonian & $\begin{array}{l}\text { 3, including: } \\
2 \text { isocrinids and } 1 \text { comatulid }\end{array}$ & $\begin{array}{l}\text { Isocrinids: } \\
\text { Chariocrinus andreae } \\
\text { Balanocrinus berchteni } \\
\text { Comatulids: } \\
\text { Paracomatula helvetica }\end{array}$ \\
\hline $\begin{array}{l}\mathrm{C} \text { - southern margin } \\
\text { of the Holy Cross } \\
\text { Mountains; Central } \\
\text { European province }\end{array}$ & Callovian & $\begin{array}{l}\text { 2, including: } \\
1 \text { isocrinid and } 1 \text { cyclocrinid }\end{array}$ & $\begin{array}{c}\text { Isocrinids: } \\
\text { Chariocrinus andreae } \\
\text { Cyclocrinids (order uncertain according to Hess } \\
\text { \& Messing, 2011): } \\
\text { Cyclocrinus macrocephalus } \\
\end{array}$ \\
\hline $\begin{array}{l}\text { D - southern part of } \\
\text { the Polish Jura; } \\
\text { Central European } \\
\text { province }\end{array}$ & Bathonian & $\begin{array}{c}\text { 6, including: } \\
3 \text { isocrinids, } 2 \text { comatulids and } 1 \\
\text { cyrtocrinid }\end{array}$ & $\begin{array}{c}\text { Isocrinids: } \\
\text { Chariocrinus andreae } \\
\text { Balanocrinus berchteni } \\
\text { Isocrinus bajociensis } \\
\text { Comatulids: } \\
\text { Paracomatula helvetica } \\
\text { Palaeocomaster sp. } \\
\text { Cyrtocrinids: } \\
\text { Cyrtocrinida indet. (=Millericrinina in Salamon \& } \\
\text { Zaton, 2007) }\end{array}$ \\
\hline
\end{tabular}




\begin{tabular}{|c|c|c|c|}
\hline $\begin{array}{l}\text { D - southern part of } \\
\text { the Polish Jura; } \\
\text { Central European } \\
\text { province }\end{array}$ & Callovian & $\begin{array}{c}\text { 15, including: } \\
3 \text { isocrinids, } 11 \text { cyrtocrinids and } \\
1 \text { cyclocrinid }\end{array}$ & $\begin{array}{c}\text { Isocrinids: } \\
\text { Chariocrinus andreae } \\
\text { Balanocrinus subteres } \\
\text { Balanocrinus pentagonalis (=Balanocrinus hessi } \\
\text { in Salamon \& Zatoń, 2006) } \\
\text { Cyrtocrinids: } \\
\text { Cyrtocrinida indet. (=Millericrinina in Salamon \& } \\
\text { Zatoń, 2007) } \\
\text { Phyllocrinus } \mathrm{sp} . \\
\text { Phyllocrinus stellaris } \\
\text { Phyllocrinus belbekensis } \\
\text { Tetracrinus moniliformis } \\
\text { Sclerocrinus sp. } \\
\text { Cyrtocrinus sp. } \\
\text { Pilocrinus moussoni } \\
\text { Dolichocrinus aberrans } \\
\text { Fischericrinus ausichi } \\
\text { Lonchocrinus dumortieri } \\
\text { Cyclocrinids: } \\
\text { Cyclocrinus macrocephalus }\end{array}$ \\
\hline $\begin{array}{l}\text { E - Tatra Mountains; } \\
\text { Tethyan province }\end{array}$ & Bathonian & $\begin{array}{c}\text { 8, including: } \\
6 \text { isocrinids, } 1 \text { cyrtocrinid and } 1 \\
\text { cyclocrinid }\end{array}$ & $\begin{array}{c}\text { Isocrinids: } \\
\text { Isocrinus } \mathrm{sp} . \\
\text { Isocrinus bathonicus } \\
\text { Isocrinus nicoleti } \\
\text { Isocrinus pendulus } \\
\text { Balanocrinus } \mathrm{sp} \text {. } \\
\text { Pentacrinites dargniesi } \\
\text { Cyrtocrinids: } \\
\text { Cyrtocrinida indet. } \\
\text { Cyclocrinids: } \\
\text { Cyclocrinus rugosus } \\
\end{array}$ \\
\hline $\begin{array}{l}\text { E - Tatra Mountains; } \\
\text { Tethyan province }\end{array}$ & Callovian & $\begin{array}{l}\text { 3, including: } \\
1 \text { isocrinid, } 1 \text { cyrtocrinid and } 1 \\
\text { roveacrinid }\end{array}$ & $\begin{array}{l}\text { Isocrinids: } \\
\text { Isocrinus } \text { sp. } \\
\text { Cyrtocrinids: } \\
\text { Cyrtocrinida indet. } \\
\text { Roveacrinids: } \\
\text { Saccocoma } \text { sp. }\end{array}$ \\
\hline $\begin{array}{l}\text { F - Pieniny Klippen } \\
\text { Belt; Tethyan } \\
\text { province }\end{array}$ & Bathonian & $\begin{array}{l}\text { 16, including: } \\
10 \text { isocrinids, } 5 \text { cyrtocrinids and } \\
1 \text { roveacrinid }\end{array}$ & $\begin{array}{l}\text { Isocrinids: } \\
\text { Chariocrinus andreae } \\
\text { Isocrinus sp. } \\
\text { Isocrinus bathonicus } \\
\text { Isocrinus nicoleti } \\
\text { Isocrinus pendulus } \\
\text { Balanocrinus } \text { sp. } \\
\text { Balanocrinus berchteni } \\
\text { Balanocrinus pentagonalis } \\
\text { Balanocrinus subteres } \\
\text { Pentacrinites dargniesi } \\
\text { Cyrtocrinids: } \\
\text { Cyrtocrinida indet. } \\
\text { Plicatocrinus tetragonus } \\
\text { Lonchocrinus dumortieri } \\
\text { Remisovicrinus } \text { sp. } \\
\text { Dolichocrinus } \text { sp. aberrans } \\
\text { Roveacrinids: } \\
\text { Saccocoma } \text { sp. }\end{array}$ \\
\hline
\end{tabular}




\begin{tabular}{|c|c|c|c|}
\hline $\begin{array}{l}\text { F - Pieniny Klippen } \\
\text { Belt; Tethyan } \\
\text { province }\end{array}$ & Callovian & $\begin{array}{l}\text { 14, including: } \\
2 \text { isocrinids, } 9 \text { cyrtocrinids, } 1 \\
\text { roveacrinid, and } 2 \text { cyclocrinids }\end{array}$ & $\begin{array}{c}\text { Isocrinids: } \\
\text { Balanocrinus subteres } \\
\text { Balanocrinus pentagonalis } \\
\text { Cyrtocrinids: } \\
\text { Cyrtocrinida indet. } \\
\text { Lonchocrinus dumortieri } \\
\text { Remisovicrinus sp. } \\
\text { Dolichocrinus cf. aberrans } \\
\text { Eudesicrinus } \text { sp. } \\
\text { Pilocrinus moussoni } \\
\text { Gammarocrinites sp. } \\
\text { Sclerocrinus compressus } \\
\text { Phyllocrinus sp. } \\
\text { Roveacrinids: } \\
\text { Saccocoma } \text { sp. } \\
\text { Cyclocrinids: } \\
\text { Cyclocrinus } \text { sp. } \\
\text { Cyclocrinus rugosus }\end{array}$ \\
\hline
\end{tabular}

1 


\section{Table 3(on next page)}

Number of collected crinoid remains during observation of respective cores and maceration process. 


\begin{tabular}{|l|l|}
\hline \multicolumn{1}{|c|}{ Species } & \multicolumn{1}{c|}{ Details } \\
\hline Isocrinida indet. & $\begin{array}{l}\text { Plenty of more or less complete columnals, brachials, } \\
\text { and cirrals }\end{array}$ \\
\hline Isocrinus nicoleti (Desor, 1845) & Plenty of more or less complete, isolated columnals \\
\hline Chariocrinus andreae (Desor, 1845) & Plenty of more or less complete, isolated columnals \\
\hline Balanocrinus subteres (Münster in Goldfuss, 1826) & Plenty of more or less complete, isolated columnals \\
\hline Balanocrinus pentagonalis (Goldfuss, 1826-1844) & 21 almost complete columnals \\
\hline Pentacrinites dargniesi Terquem \& Jourdy, 1869 & Plenty of cirrals, 14 almost complete columnals \\
\hline Cyrtocrinida indet. & $\begin{array}{l}\text { Plenty of cup remains and partly preserved columnals } \\
\text { and 27 nearly complete columnals }\end{array}$ \\
\hline Phyllocrinus sp. & Two cups \\
\hline
\end{tabular}




\section{Table 4 (on next page)}

\section{Analysis Of Variance (ANOVA)}

(A) ANOVA test between different substrate types (Claystones, Sandstones and Limestones).

(B) Tukey's HSD (honestly significant difference) test for pairwise comparisons. (C) ANOVA test between different paleodepth parameters (Near shore, Shallow-marine, Mid-ramp and Off shore). (D) Tukey's HSD (honestly significant difference) test for pairwise comparisons. 
1

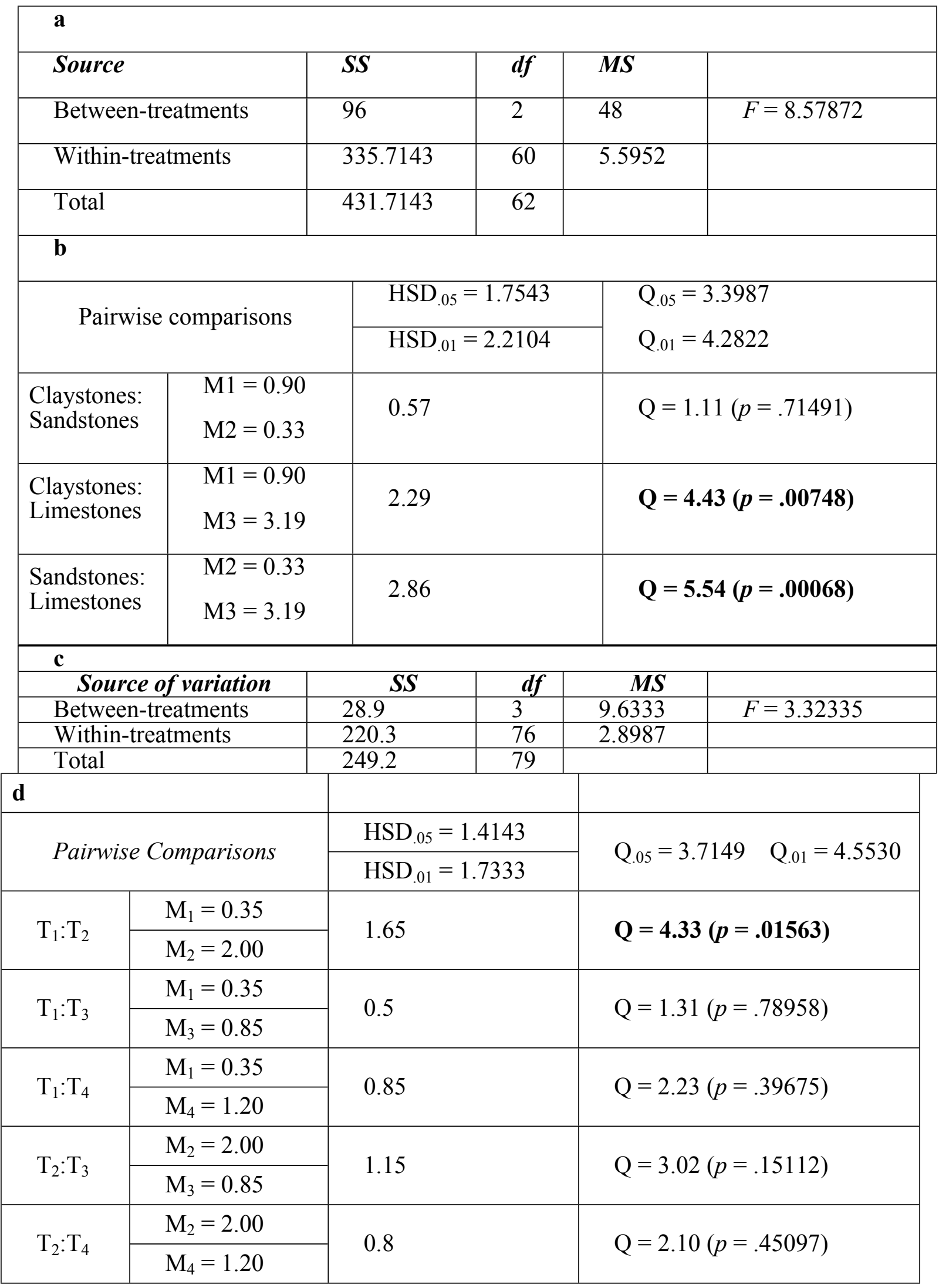




\begin{tabular}{|l|l|l|l|}
$\mathrm{T}_{3}: \mathrm{T}_{4}$ & $\mathrm{M}_{3}=0.85$ & \multirow{2}{*}{0.35} & $\mathrm{Q}=0.92(p=.91521)$ \\
\cline { 2 - 2 } & $\mathrm{M}_{4}=1.20$ & & \\
\hline
\end{tabular}

2

3 


\section{Figure 1}

\section{Location maps}

(A) Palaeogeographic map of central Europe during the Middle Jurassic (modified after Šimkevičius et al., 2003). A-Bathonian and Callovian exposures of the southern part of the Polish Jura; $B$ - Bathonian and Callovian exposures of the southern margin of the Holy Cross Mountains; C - Callovian exposure of the glacial drift in Łuków; G1-G6 - location of the Bathonian-Callovian boreholes described in this constribution [TfuszCZ IGI (G1), Siedliska IGI (G2), Kock IG2 (G3), Żyrzyn IG 1 (G4), Maciejowice IG1 (G5), Magnuszew IG1 (G6)], D location of borehole Żebrak IG1 (details in Salamon \& Feldman-Olszewska, 2018); A-D - Central European province; $E$ - Bathonian and Callovian exposures of the Tatra Mountains; F Bathonian and Callovian exposures of the Pieniny Klippen Belt; $E, F$ - Tethyan province. (B) Map of Callovian lithofacies noted in Poland (modified after Dayczak-Calikowska \& Moryc, 1988). 
A

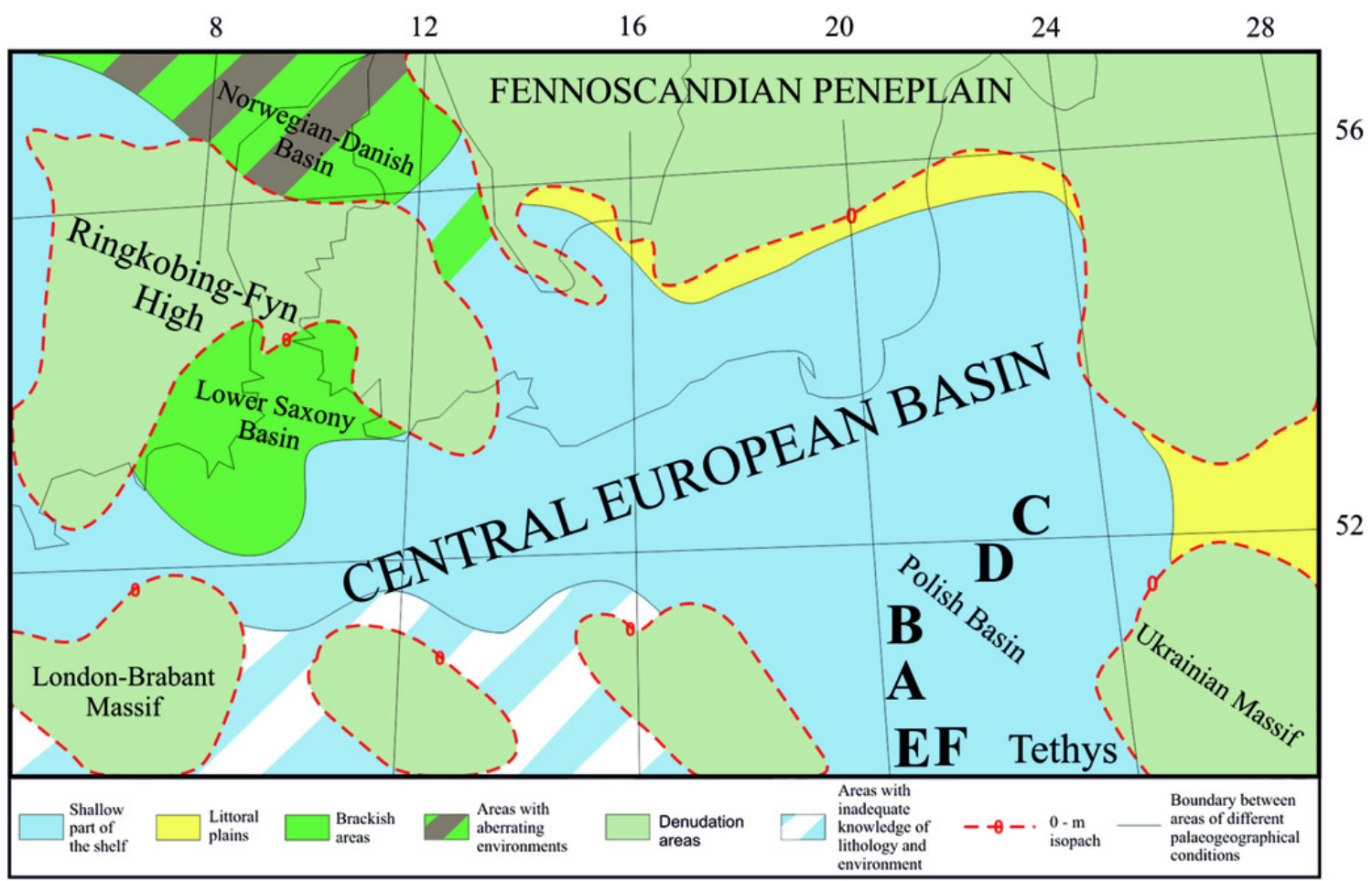

B

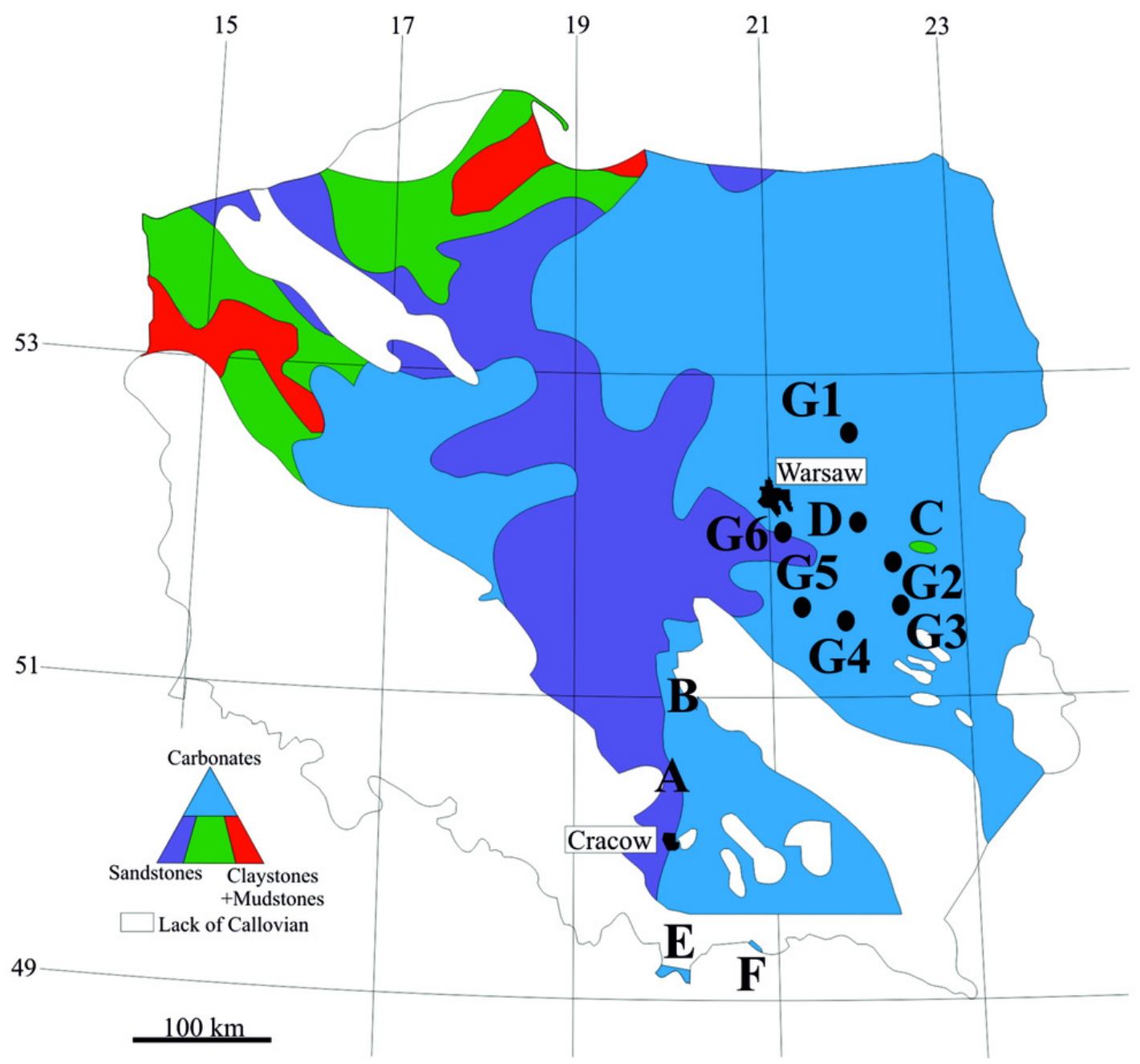

PeerJ reviewing PDF | (2021:03:59630:2:1:NEW 27 Jul 2021) 
Figure 2

Model showing distribution of selected Callovian crinoids.

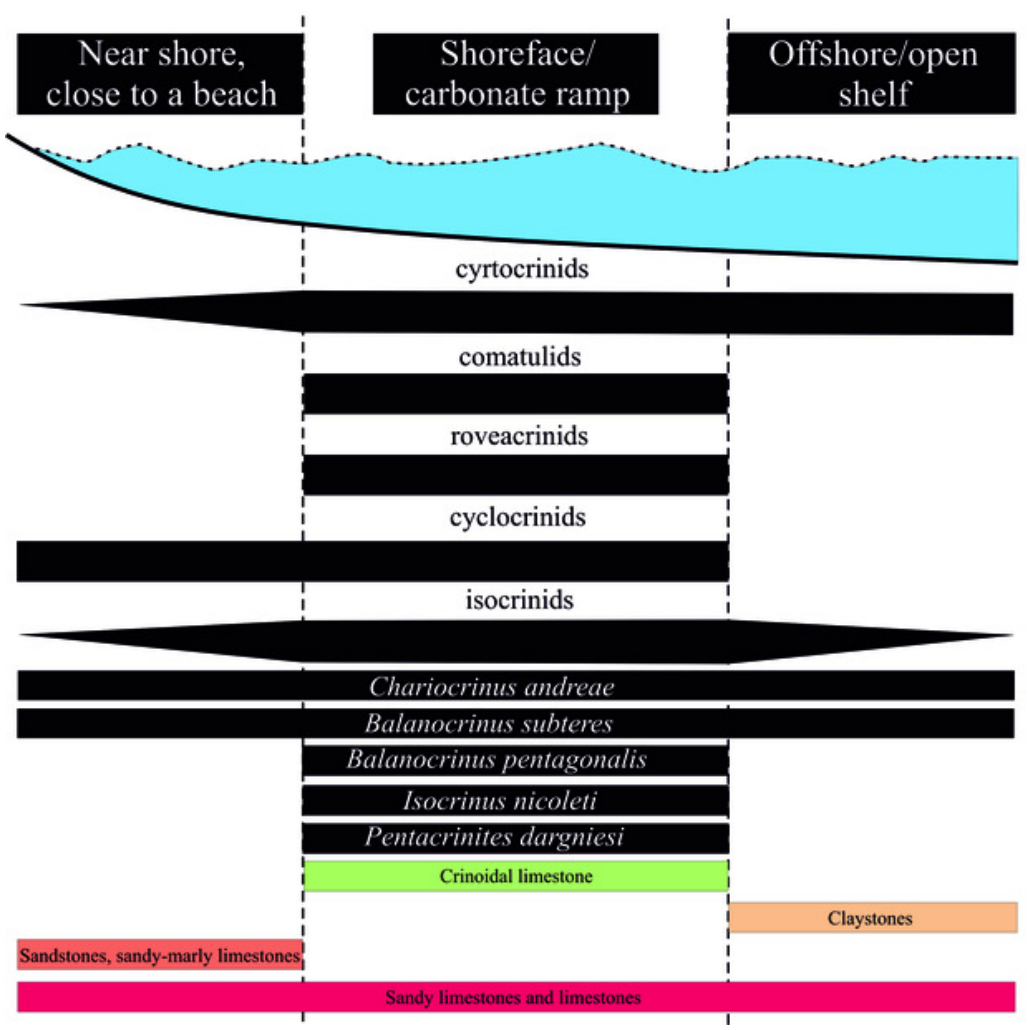




\section{Figure 3}

Cyclocrinid remains from southern Poland.

(A) Columnal, articular facet. (B) Brachial plate. Scale bar equals $1 \mathrm{~mm}$. Blue arrows mark granules covering the articular facet of columnal.

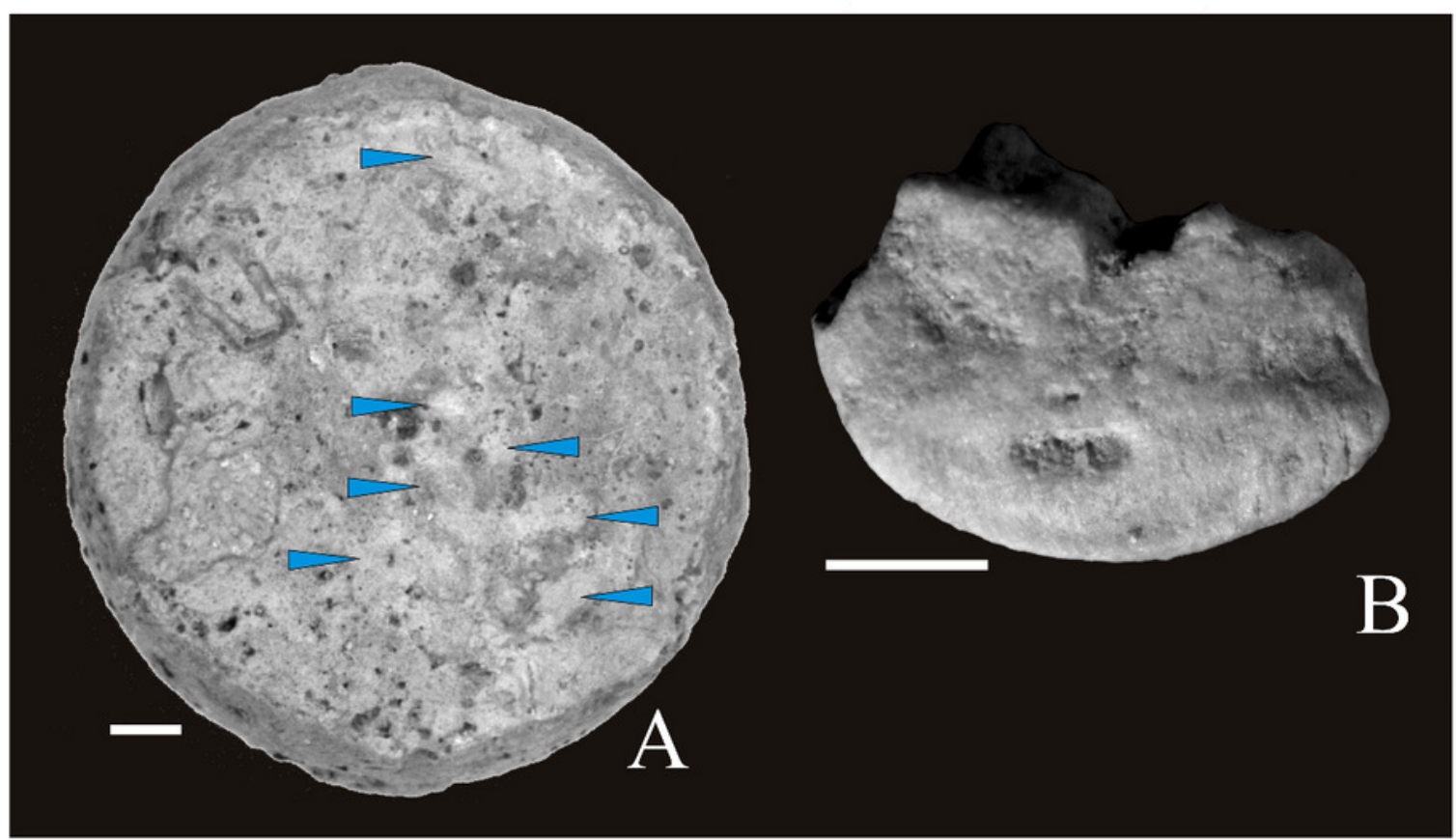

